Supporting Information

\title{
Bifunctional porous cobalt phosphide foam for high- current-density alkaline water electrolysis with 4000- hour long stability
}

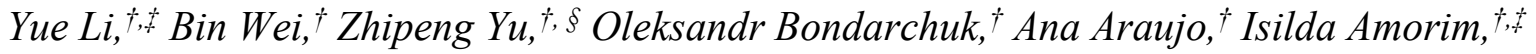
Nan Zhang,,$^{\dagger}$ Junyuan Xu,,$^{\dagger^{*}}$ Isabel C. Neves ${ }^{t, l}$ and Lifeng Liu $广^{\dagger^{*}}$

$\dagger$ International Iberian Nanotechnology Laboratory (INL), Avenida Mestre Jose Veiga, 4715330 Braga, Portugal

$\$$ Centre of Chemistry, University of Minho, Gualtar Campus, Braga, 4710-057, Portugal

$\S$ Laboratory of Catalysis and Materials (LSRE-LCM), Faculdade de Engenharia, Universidade do Porto, Rua Dr. Roberto Frias, 4200-465 Porto, Portugal

" Centre of Biological Engineering, University of Minho, Campus de Gualtar, 4710-057 Braga, Portugal

\section{AUTHOR INFORMATION}

\section{Corresponding Author}

J.Y.Xu (junyuan.xu@inl.int); L. Liu (lifeng.liu@,inl.int)

Number of pages: 31

Number of Figures: 26

Number of Tables: 1 


\section{Contents:}

Figure S1 Performance optimization of porous Co-P at different phosphorization temperatures of 500,600 and $700{ }^{\circ} \mathrm{C}$. The $i R$-corrected polarization curves were recorded at a scan rate of 5 $\mathrm{mV} \mathrm{s}^{-1}$ for (a) OER in $1.0 \mathrm{M} \mathrm{KOH}$, (b) HER in $1.0 \mathrm{M} \mathrm{KOH}$ and (c) HER in $0.5 \mathrm{M} \mathrm{H}_{2} \mathrm{SO}_{4}$. Figure S2 SEM images showing the morphology of P-CF at different magnifications.

Figure S3 SEM images showing the morphology of A-CF at different magnifications.

Figure S4 SEM images showing the morphology of AA-CF at different magnifications.

Figure S5 SEM images showing the morphology of porous Co-P at different magnifications.

Figure S6 XPS survey spectrum of the porous Co-P foam.

Figure S7 SEM images showing the morphology of P-CoP at different magnifications.

Figure S8 SEM images showing the morphology of A-CoP at different magnifications.

Figure S9 XRD patterns of P-CF and A-CF. The standard powder diffraction patterns of Co (ICDD No. 00-001-1254) is given for reference.

Figure S10 XRD pattern of AA-CF. The standard powder diffraction patterns of Co (ICDD No. 00-001-1254), $\mathrm{Co}_{3} \mathrm{O}_{4}$ (ICDD No. 01-071-0816), $\mathrm{Co}_{3} \mathrm{O}_{4}$ (ICDD No. 04-014-7746) and $\mathrm{Co}_{3} \mathrm{O}_{4}$ (ICDD No. 04-020-7500) are given for reference.

Figure S11 XRD pattern of the P-CoP. The standard powder diffraction patterns of Co (ICDD No. 00-001-1254), orthorhombic $\mathrm{Co}_{2} \mathrm{P}$ (ICDD No. 00-032-0306), orthorhombic CoP (ICDD No. 03-065-2593), orthorhombic $\mathrm{CoP}_{2}$ (ICDD No. 04-004-6713) are given for reference.

Figure S12 XRD pattern of A-CoP. The standard powder diffraction patterns of Co (ICDD No. 00-001-1254), orthorhombic $\mathrm{Co}_{2} \mathrm{P}$ (ICDD No. 00-032-0306), orthorhombic CoP (ICDD No. 03-065-2593), orthorhombic $\mathrm{CoP}_{2}$ (ICDD No. 04-004-6713) are given for reference.

Figure S13 High-resolution (a) Co2 $p_{3 / 2}$ and (b) P2p XPS spectra of the P-CoP. Dash lines are fitting curves of each component. 
Figure S14 High-resolution (a) Co2 $\mathrm{p}_{3 / 2}$ and (b) P2p XPS spectra of the A-CoP. Dash lines are fitting curves of each component.

Figure S15 Tafel analysis of the porous Co-P foam and other control samples for (a) HER and (b) OER tested in $1.0 \mathrm{M} \mathrm{KOH}$.

Figure S16 The Nyquist plots of porous Co-P foam and other control samples measured at (a) $\eta=200 \mathrm{mV}$ for HER and (b) $\eta=320 \mathrm{mV}$ for OER.

Figure S17 Electrochemical CV curves of (a) P-CF, (b) A-CF, (c) AA-CF, (d) P-CoP, (e) A$\mathrm{CoP}$ and (f) porous Co-P recorded at different scan rates of 5, 10, 20, 30 and $50 \mathrm{mV} \mathrm{s}^{-1} \cdot(\mathrm{g})$ Plots of the capacitive currents as a function of the scan rate for all the samples.

Figure S18 $i R$-corrected polarization curves of $\mathrm{P}-\mathrm{CoP}, \mathrm{A}-\mathrm{CoP}$ and porous Co-P recorded at a scan rate of $5 \mathrm{mV} \mathrm{s}^{-1}$ for HER in $0.5 \mathrm{M} \mathrm{H}_{2} \mathrm{SO}_{4}$.

Figure S19 $i R$-corrected chronopotentiometric curves of porous Co-P recorded at a constant current density of 500 (OER) and -500 (HER) $\mathrm{mA} \mathrm{cm}^{-2}$ in $1.0 \mathrm{M} \mathrm{KOH}$.

Figure S20 $i R$-corrected chronopotentiometric curves of porous Co-P recorded at a constant current density of -1000 (HER) $\mathrm{mA} \mathrm{cm}^{-2}$ in $0.5 \mathrm{M} \mathrm{H}_{2} \mathrm{SO}_{4}$. The experiments was stopped when the graphite rod counter electrode broke.

Figure S21 The stability of porous Co-P electrodes for overall water splitting recorded at a constant current density of $500 \mathrm{~mA} \mathrm{~cm}^{-2}$ with $i R$-correction.

Figure S22 (a-d) SEM and (e) EDX spectrum of the porous Co-P cathode after the extended overall water electrolysis test at $1000 \mathrm{~mA} \mathrm{~cm}^{-2}$ for $4000 \mathrm{~h} . \mathrm{K}$ and $\mathrm{Fe}$ are originated from the remnant $\mathrm{KOH}$ solution, and $\mathrm{Cu}$ results from the copper tape used for SEM examination.

Figure S23 XRD patterns of the porous Co-P before and after the extended stability test in 1.0 M KOH (1000 mA cm², $4000 \mathrm{~h})$. 
Figure S24 XPS spectra of the porous Co-P cathode after the extended overall water electrolysis test at $1000 \mathrm{~mA} \mathrm{~cm}^{-2}$ for $4000 \mathrm{~h}$ in $1.0 \mathrm{M} \mathrm{KOH}$. (a) Co2 $\mathrm{p}_{3 / 2}$ (b) P2p and (c) $\mathrm{O} 1 \mathrm{~s}$ spectra.

Figure S25 (a-d) SEM and (e) EDX spectrum of the porous Co-P anode after the extended overall water electrolysis test at $1000 \mathrm{~mA} \mathrm{~cm}^{-2}$ for $4000 \mathrm{~h} . \mathrm{K}$ and $\mathrm{Fe}$ are originated from the remnant $\mathrm{KOH}$ solution, and $\mathrm{Cu}$ results from the copper tape used for SEM examination.

Figure S26 XPS spectra of the porous Co-P anode after the extended overall water electrolysis test at $1000 \mathrm{~mA} \mathrm{~cm}^{-2}$ for $4000 \mathrm{~h}$ in $1.0 \mathrm{M} \mathrm{KOH}$. (a) Co2p $\mathrm{p}_{3 / 2}$ (b) P2p and (c) O1s spectra.

Table S1. Comparison of overall water splitting performance with a variety of state-of-the-art catalysts in $1.0 \mathrm{M} \mathrm{KOH}$ electrolyte. 


\section{Supporting Figures:}
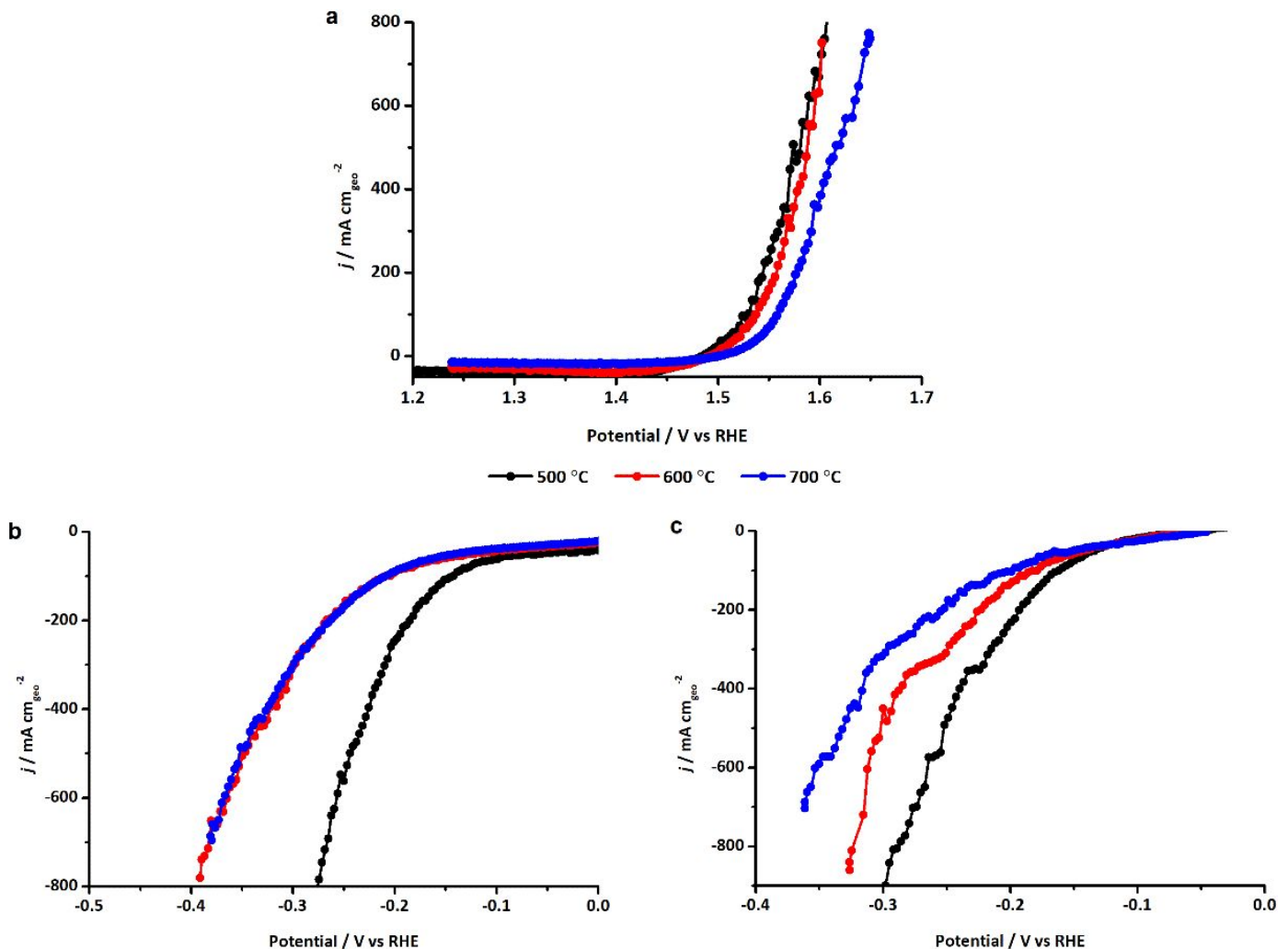

Figure S1 Performance optimization of porous Co-P at different phosphorization temperatures of 500,600 and $700{ }^{\circ} \mathrm{C}$. The $i R$-corrected polarization curves were recorded at a scan rate of 5 $\mathrm{mV} \mathrm{s}^{-1}$ for (a) OER in 1.0 M KOH, (b) HER in $1.0 \mathrm{M} \mathrm{KOH}$ and (c) HER in $0.5 \mathrm{M} \mathrm{H}_{2} \mathrm{SO}_{4}$. 

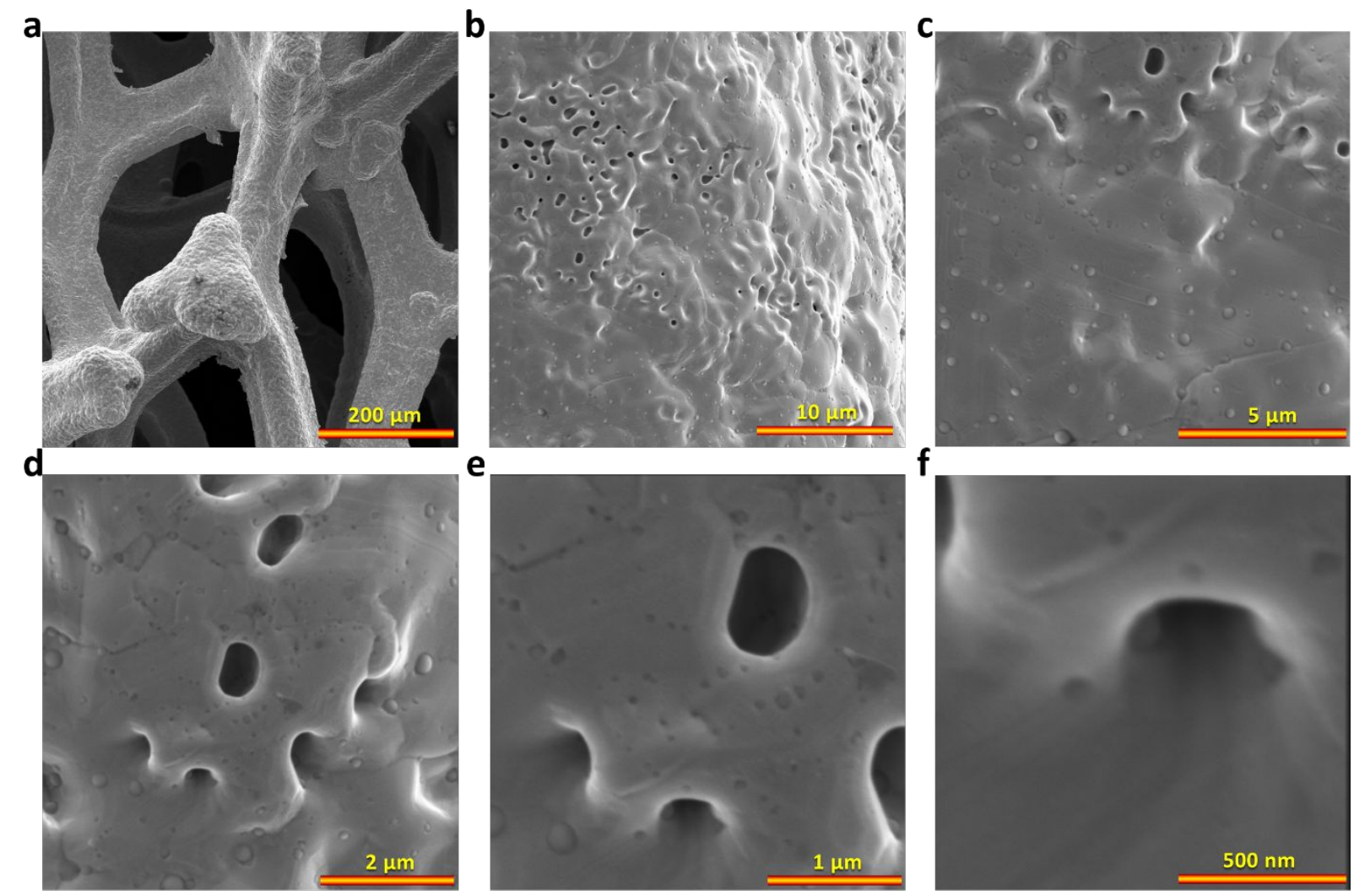

Figure S2 SEM images showing the morphology of P-CF at (a, b) low and (c-f) high magnifications. 

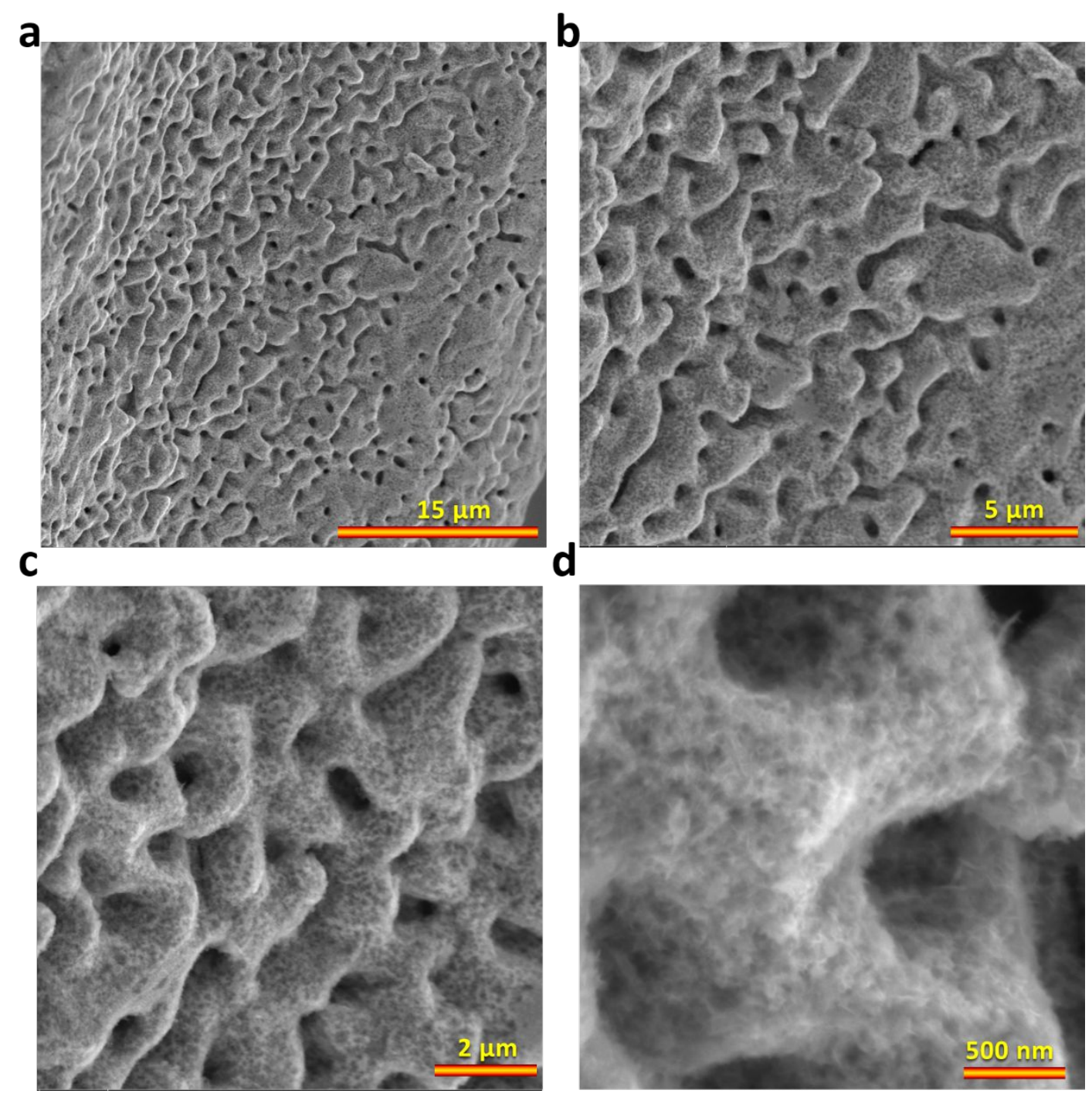

Figure S3 SEM images showing the morphology of A-CF at (a) low and (b-d) high magnifications. 

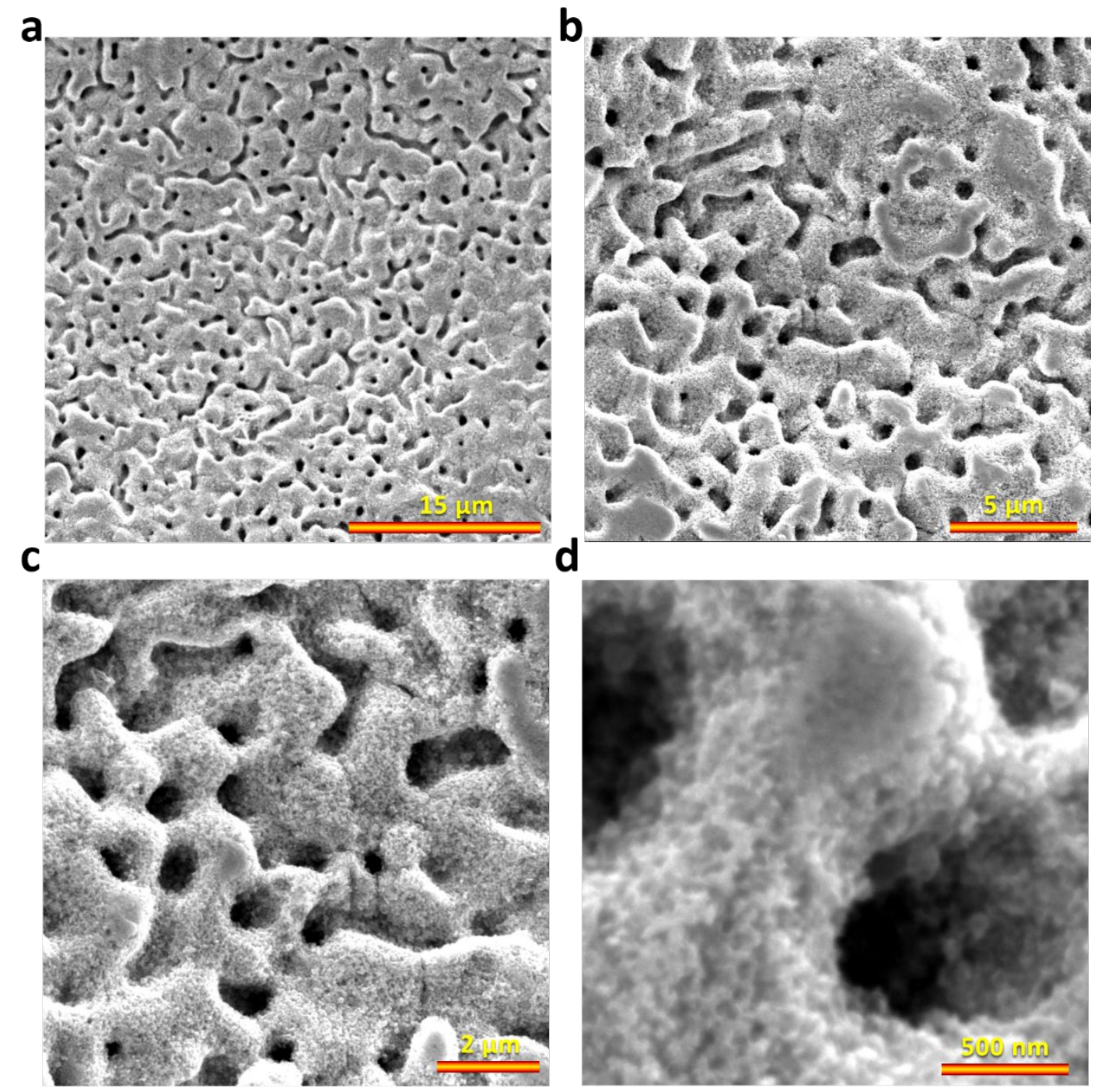

Figure S4 SEM images showing the morphology of AA-CF at (a) low and (b-d) high magnifications. 

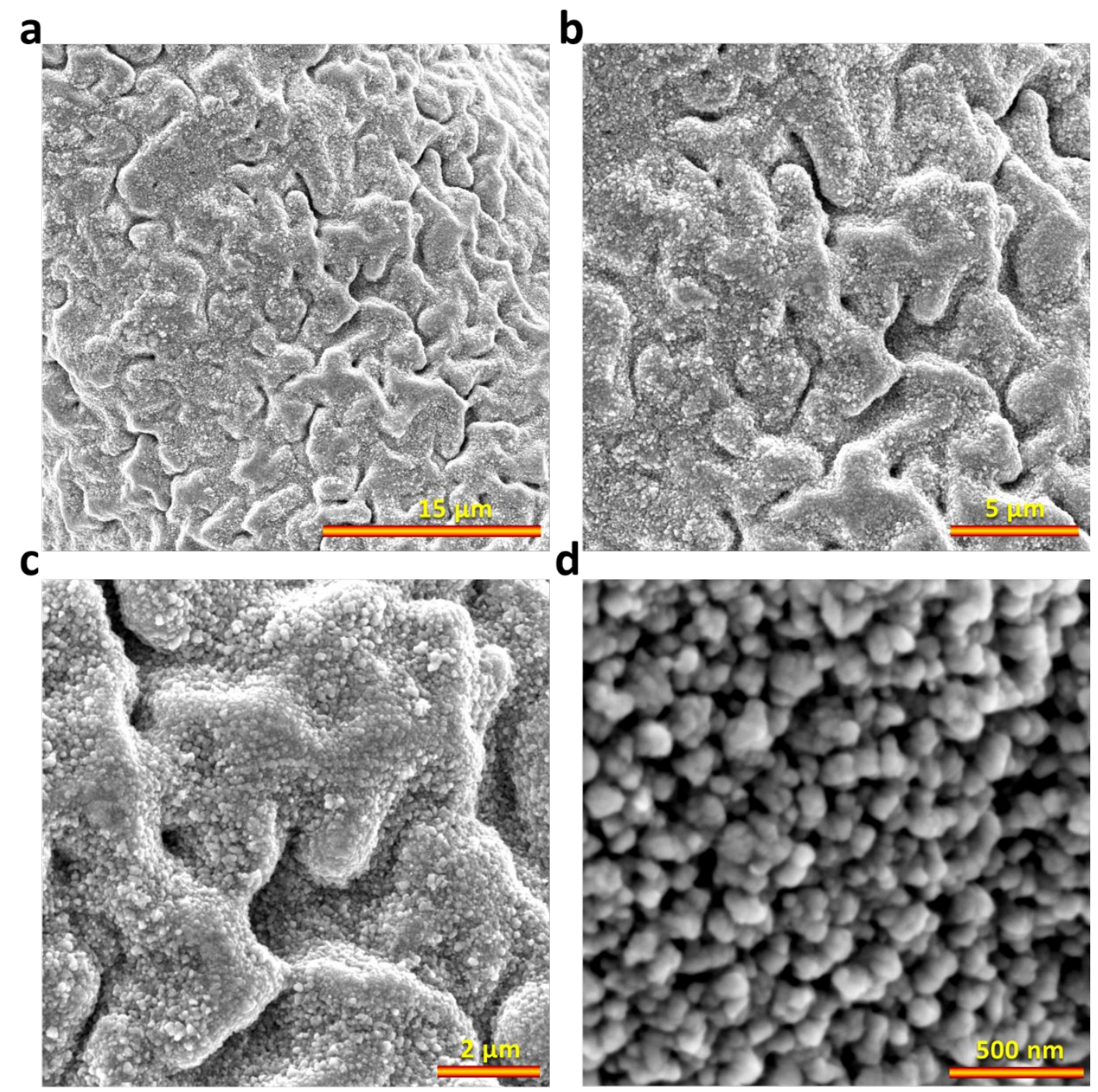

Figure S5 SEM images showing the morphology of porous Co-P at (a) low and (b-d) high magnifications. 


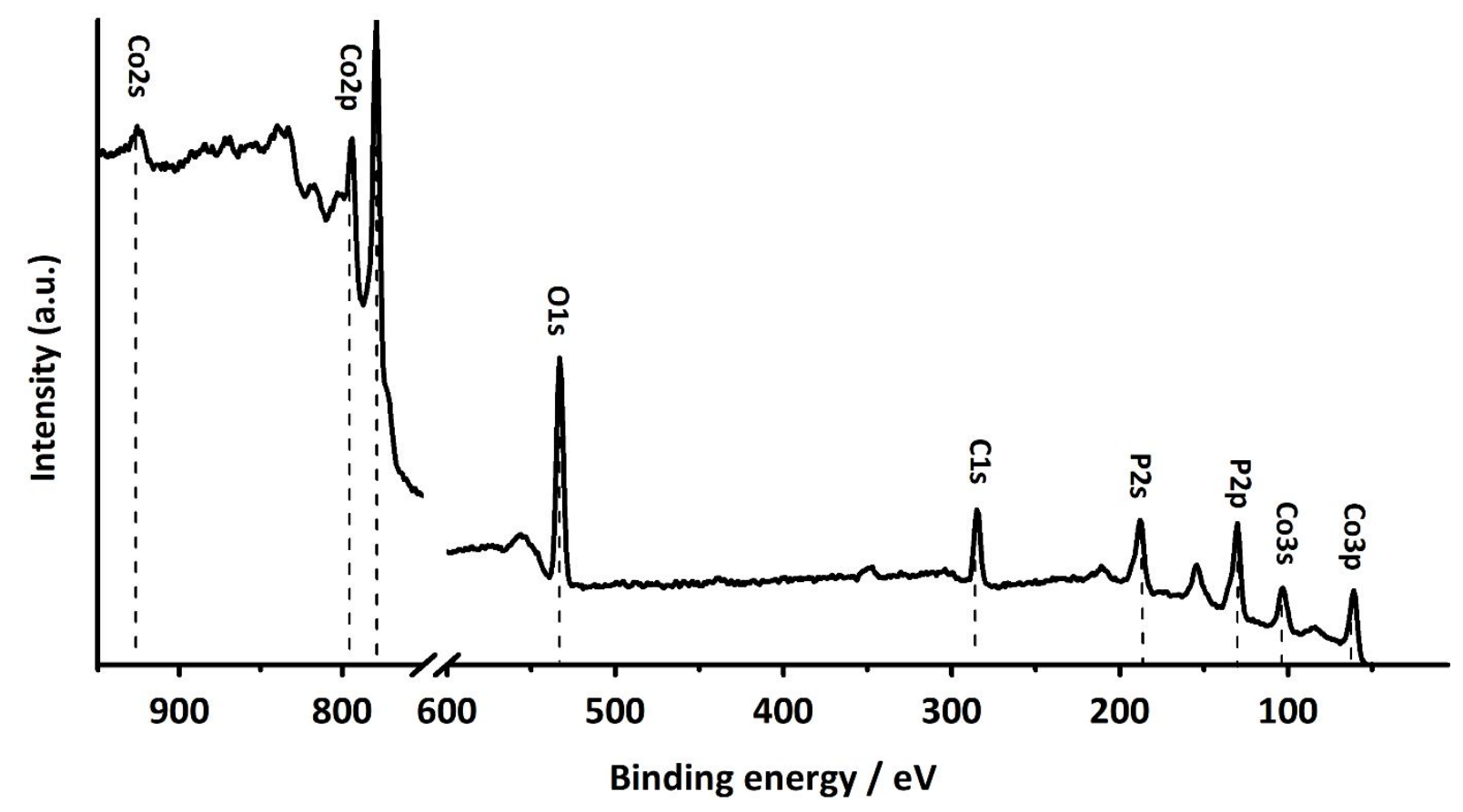

Figure S6 XPS survey spectrum of the porous Co-P foam. 

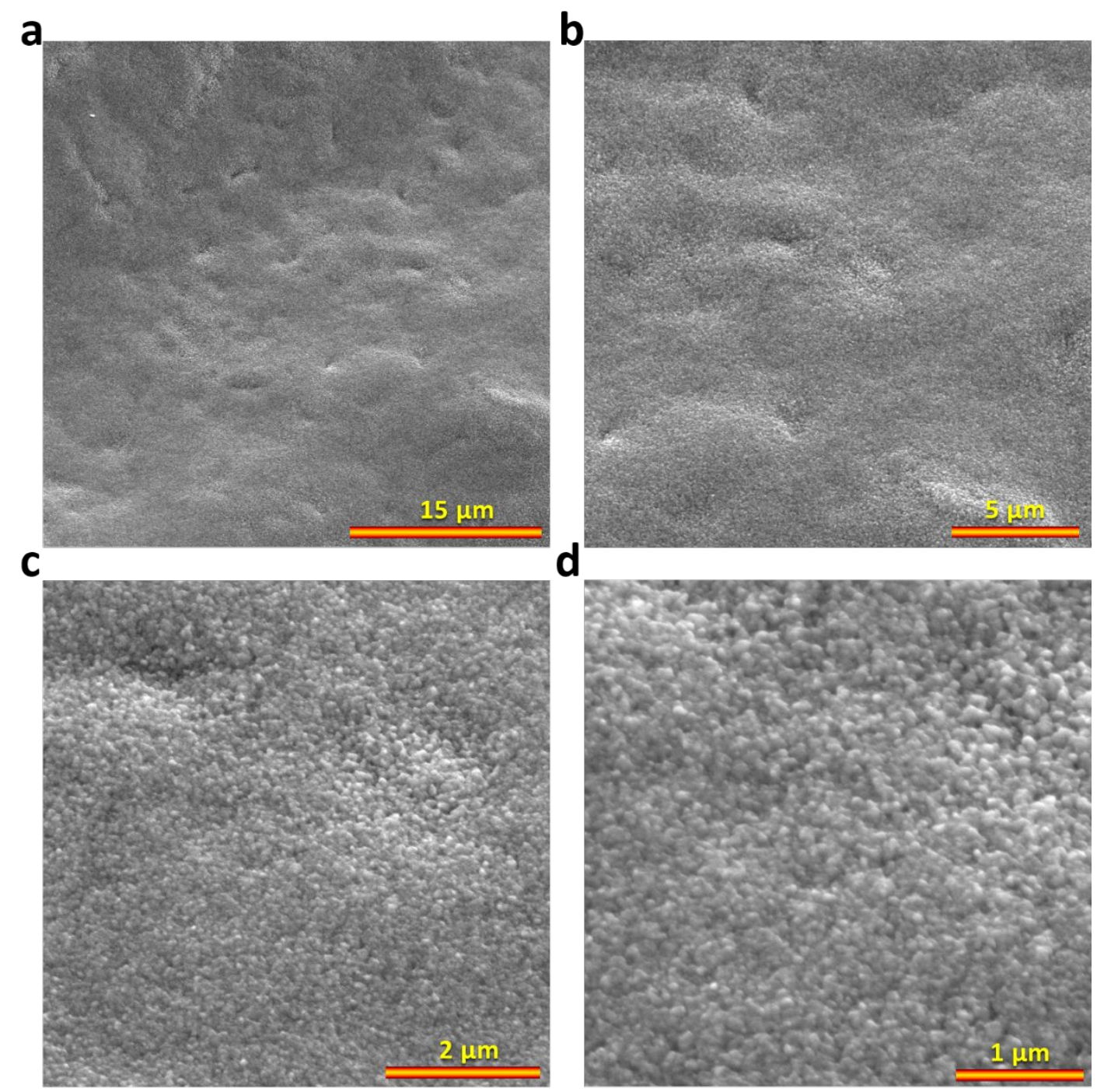

Figure S7 SEM images showing the morphology of P-CoP at (a) low and (b-d) high magnifications. 

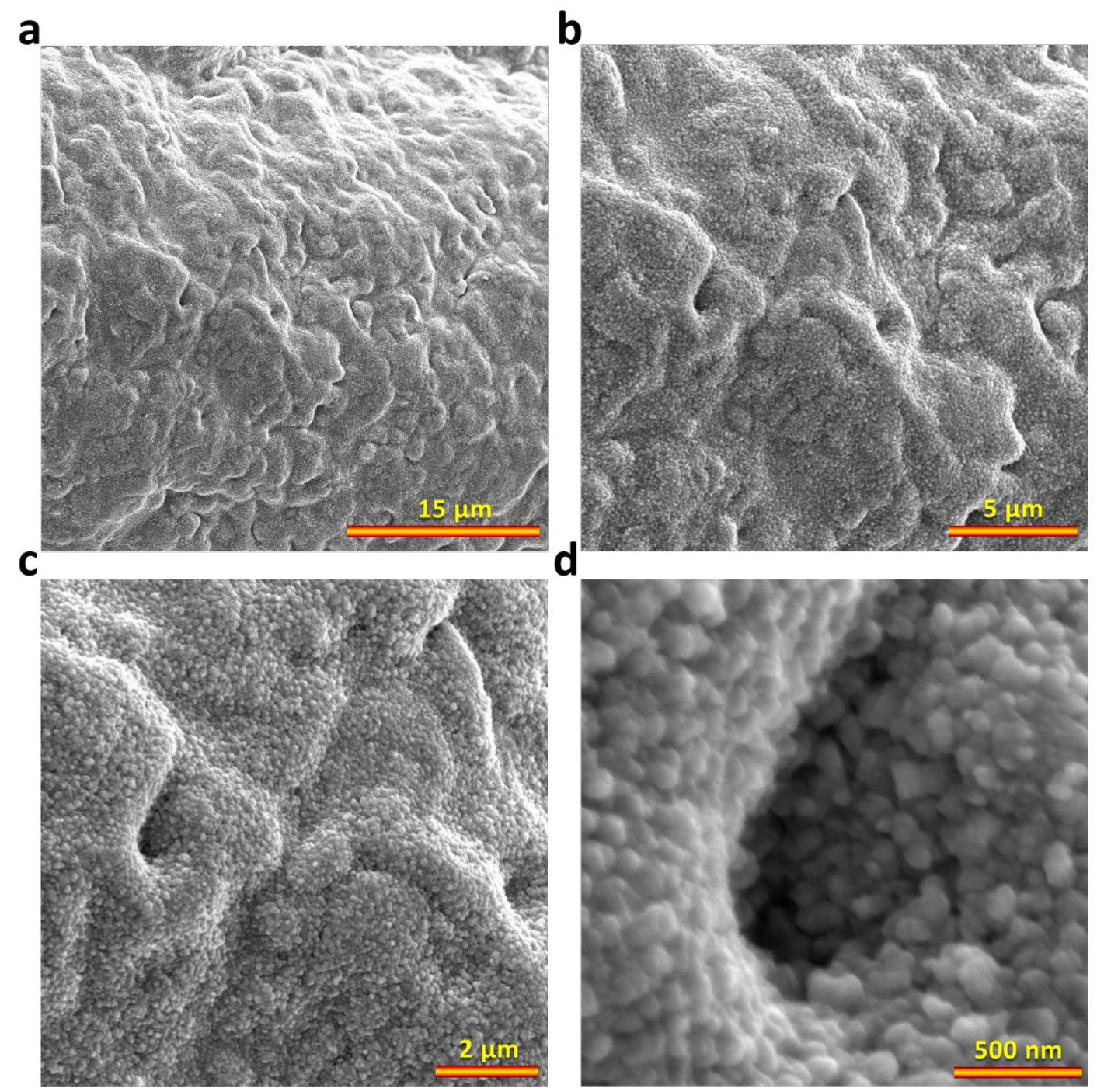

Figure S8 SEM images showing the morphology of A-CoP at (a) low and (b-d) high magnifications. 


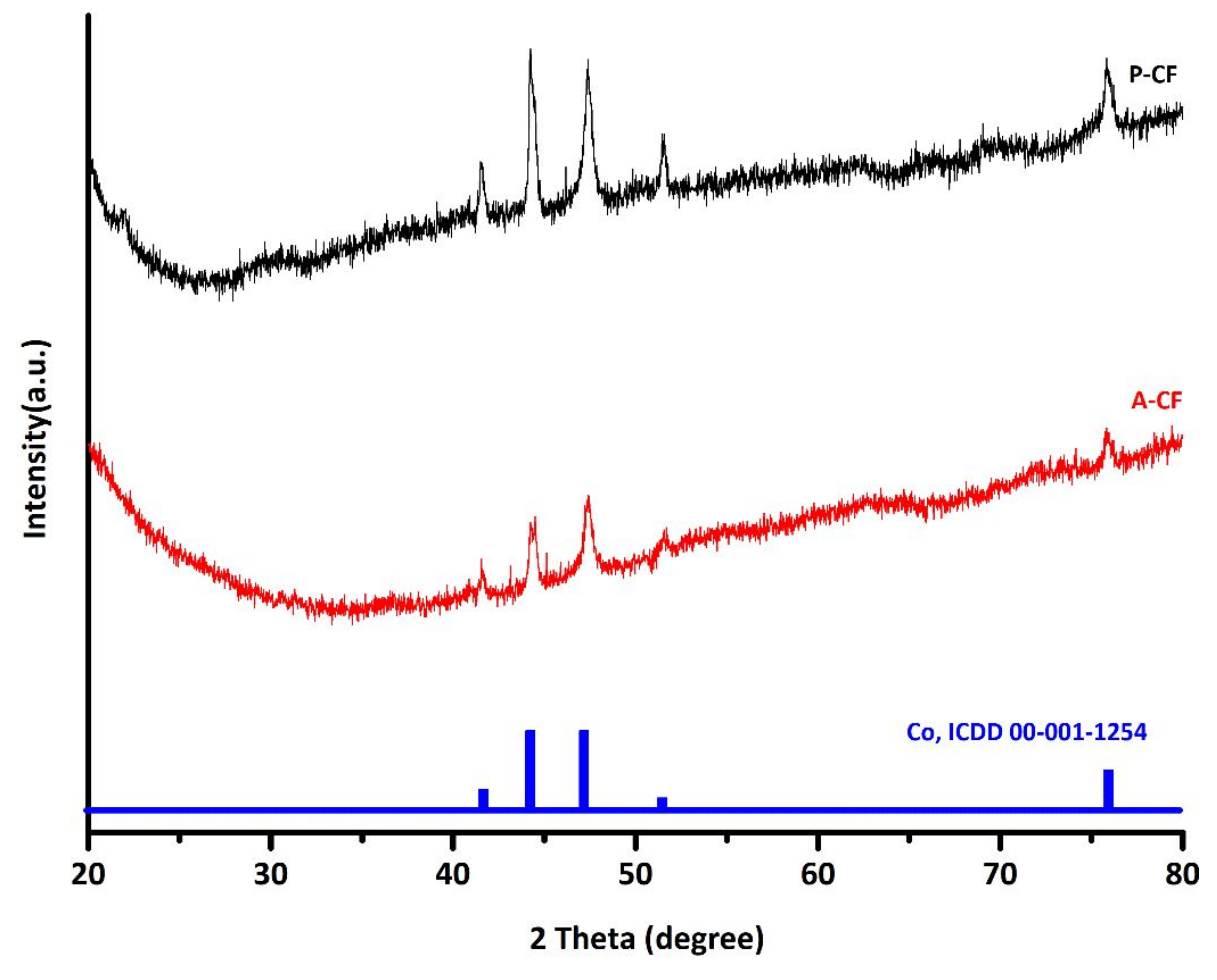

Figure S9 XRD patterns of P-CF and A-CF. The standard powder diffraction patterns of Co (ICDD No. 00-001-1254) is given for reference. 


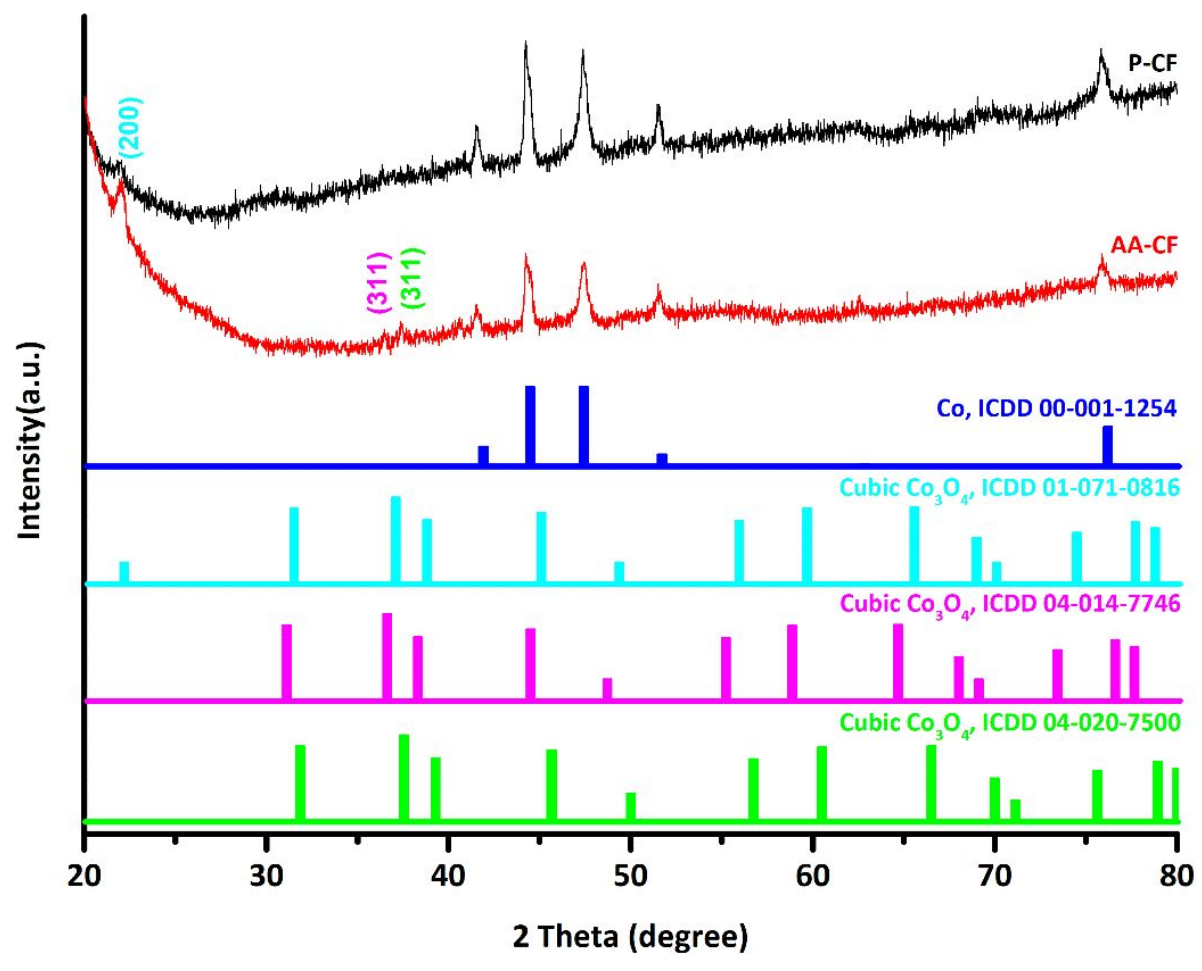

Figure S10 XRD pattern of AA-CF. The standard powder diffraction patterns of Co (ICDD No. 00-001-1254), $\mathrm{Co}_{3} \mathrm{O}_{4}$ (ICDD No. 01-071-0816), $\mathrm{Co}_{3} \mathrm{O}_{4}$ (ICDD No. 04-014-7746) and $\mathrm{Co}_{3} \mathrm{O}_{4}$ (ICDD No. 04-020-7500) are given for reference. 


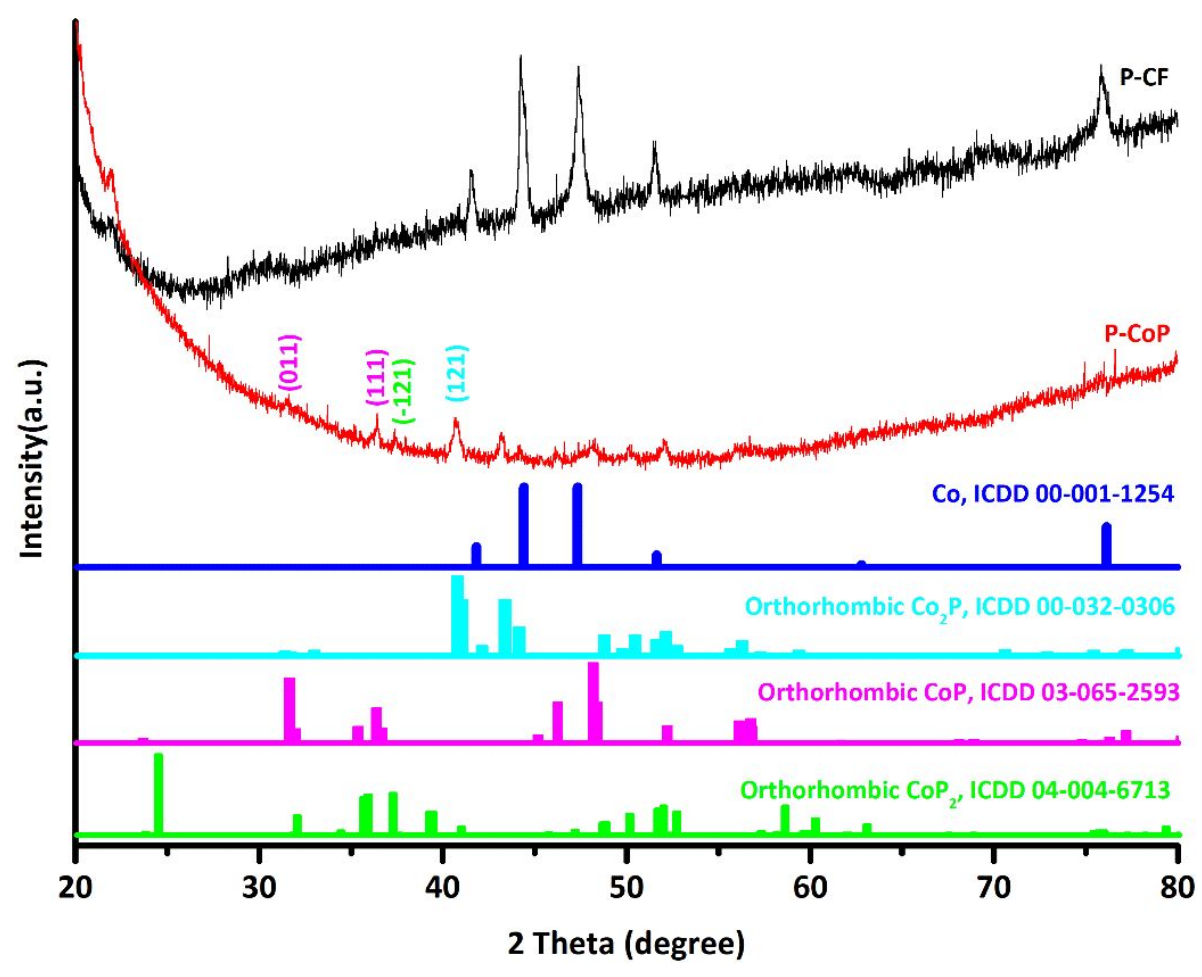

Figure S11 XRD pattern of the P-CoP. The standard powder diffraction patterns of Co (ICDD No. 00-001-1254), orthorhombic $\mathrm{Co}_{2} \mathrm{P}$ (ICDD No. 00-032-0306), orthorhombic CoP (ICDD No. 03-065-2593), orthorhombic $\mathrm{CoP}_{2}$ (ICDD No. 04-004-6713) are given for reference. 


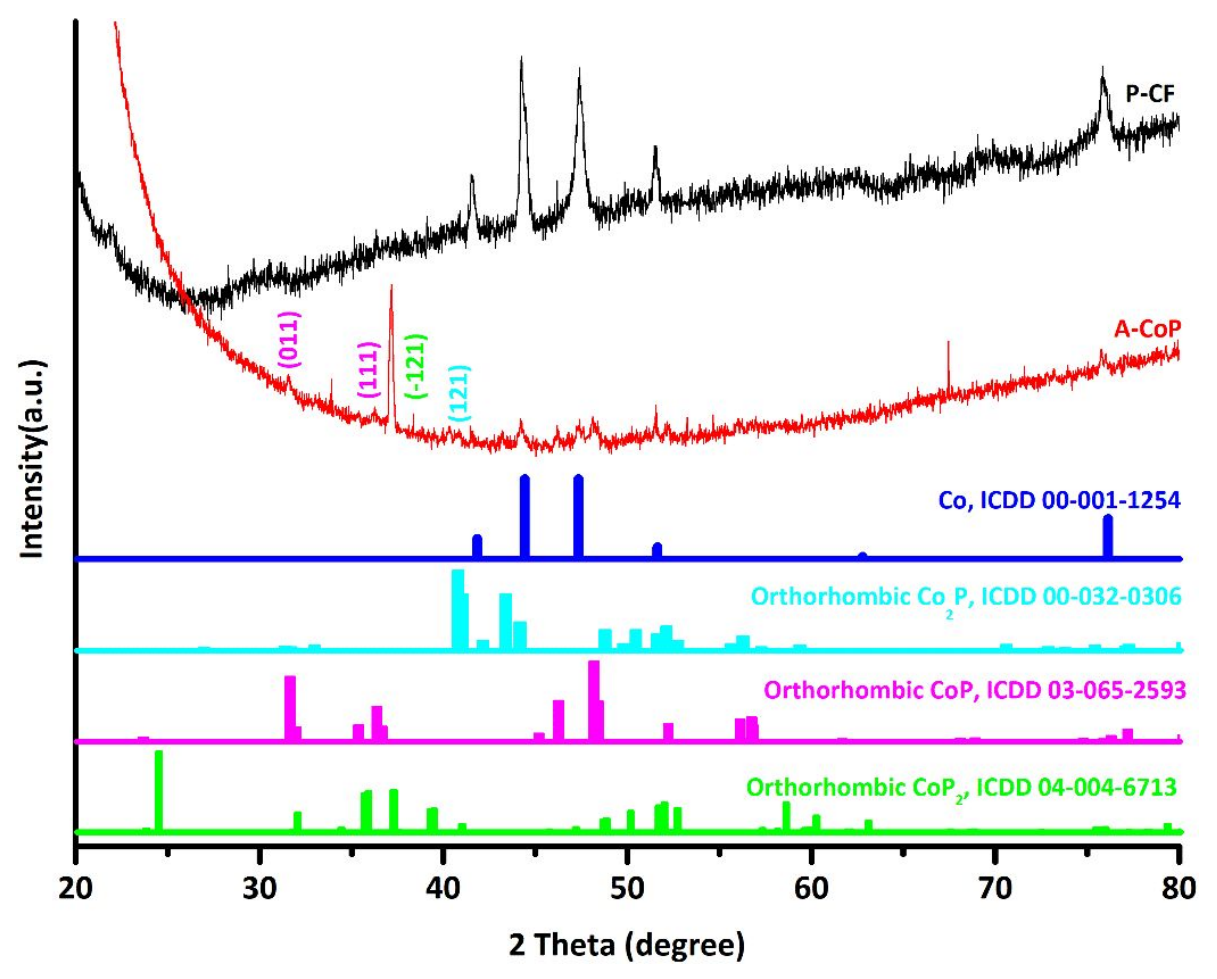

Figure S12 XRD pattern of A-CoP. The standard powder diffraction patterns of Co (ICDD No. 00-001-1254), orthorhombic $\mathrm{Co}_{2} \mathrm{P}$ (ICDD No. 00-032-0306), orthorhombic CoP (ICDD No. 03-065-2593), orthorhombic $\mathrm{CoP}_{2}$ (ICDD No. 04-004-6713) are given for reference. 


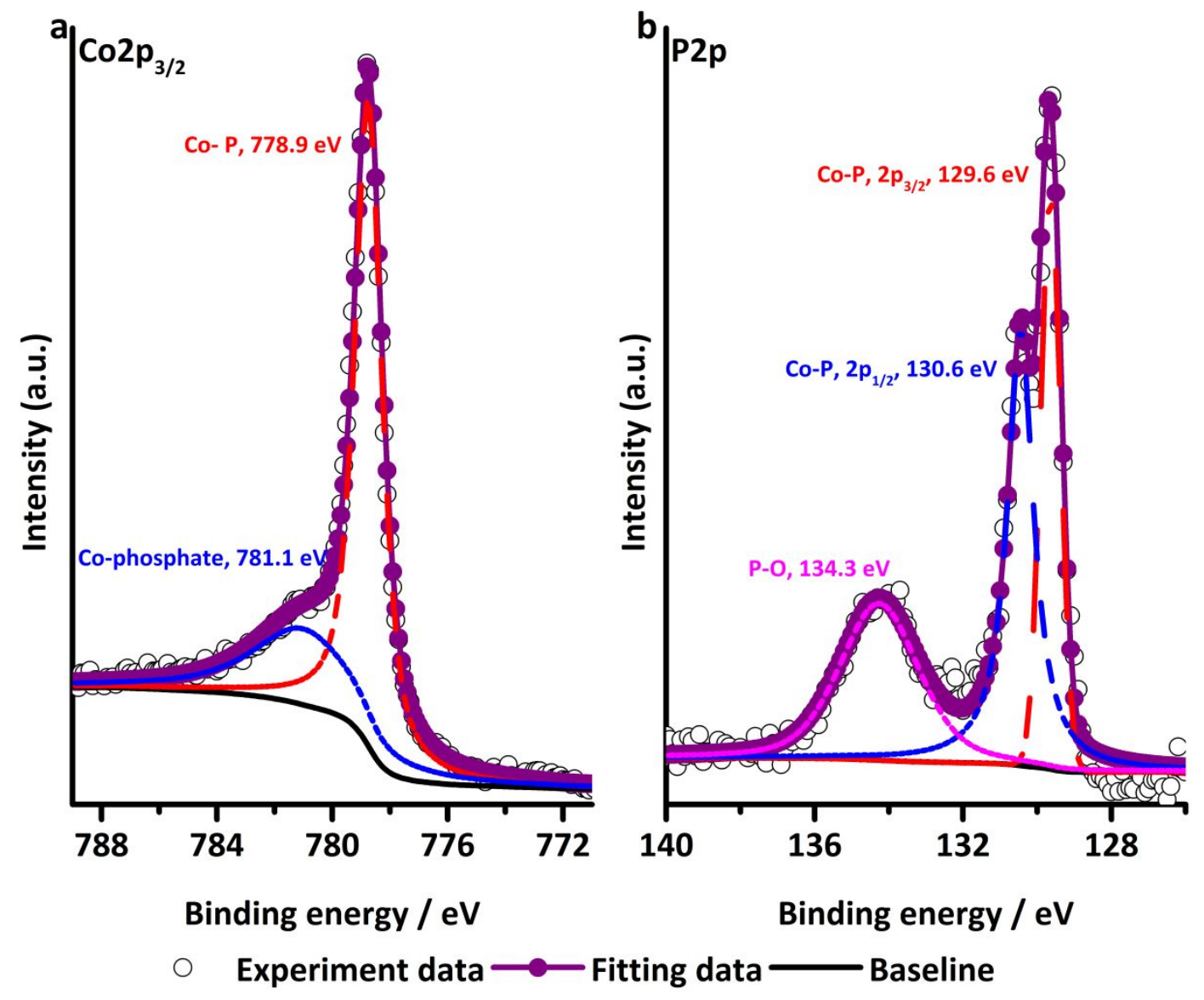

Figure S13 High-resolution (a) Co2 $p_{3 / 2}$ and (b) P2p XPS spectra of the P-CoP. Dash lines are fitting curves of each component. 


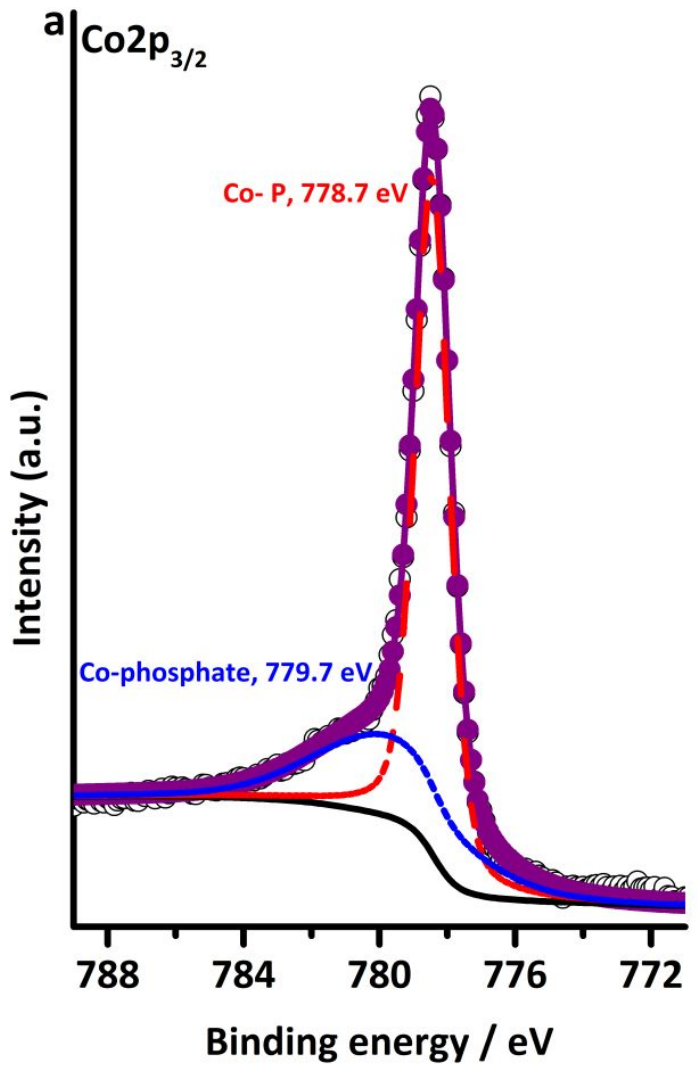

- Experiment data

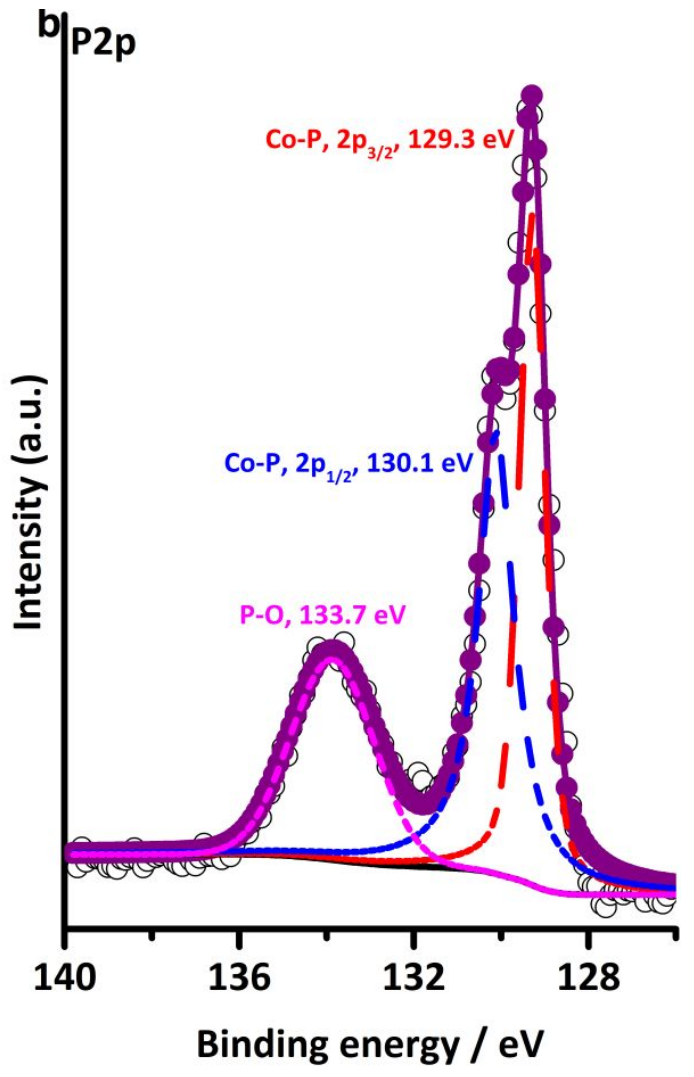

Fitting data

Figure S14 High-resolution (a) Co2 $p_{3 / 2}$ and (b) P2p XPS spectra of the A-CoP. Dash lines are fitting curves of each component. 

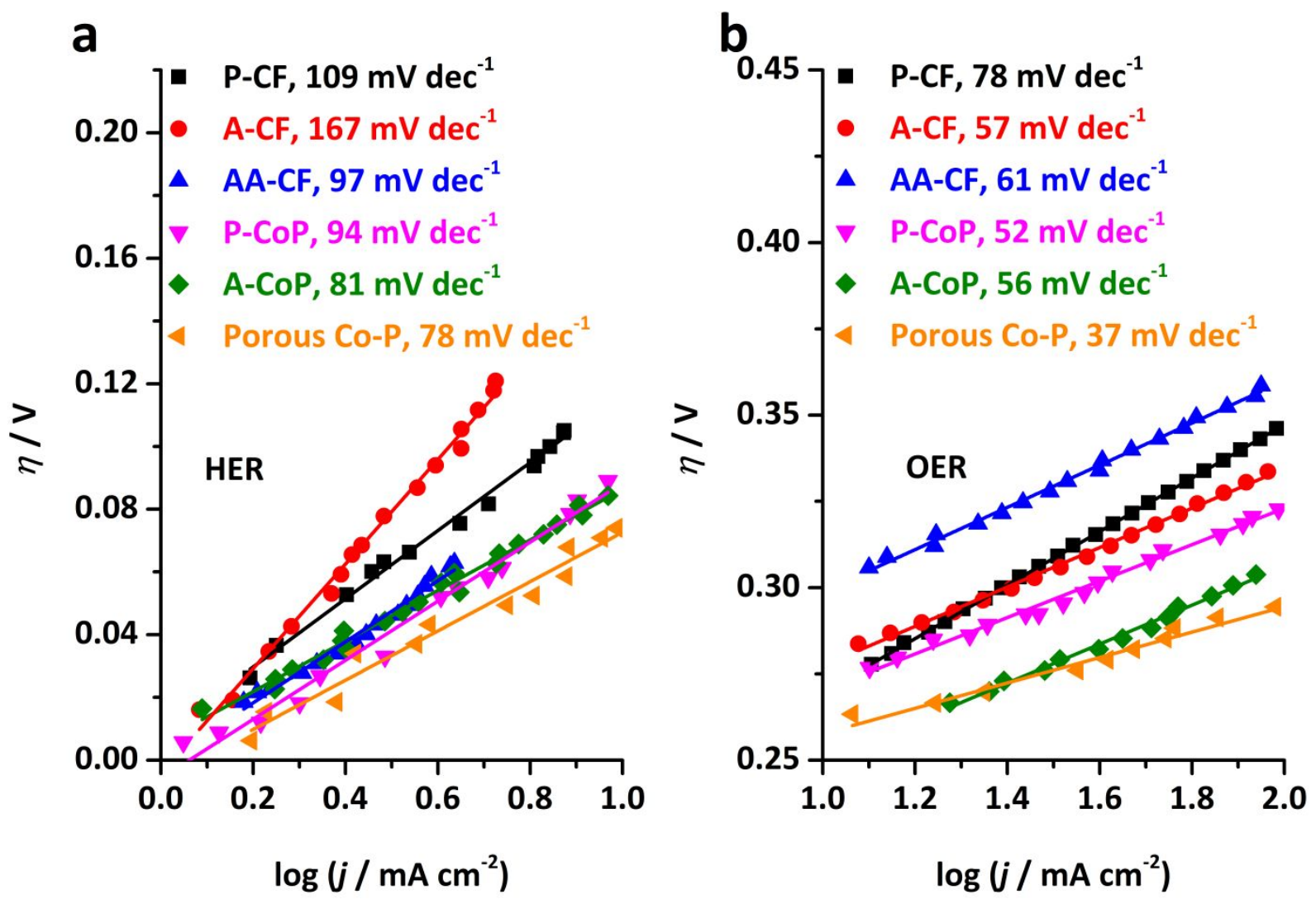

Figure S15 Tafel analysis of the porous Co-P foam and other control samples for (a) HER and (b) OER tested in $1.0 \mathrm{M} \mathrm{KOH}$. 

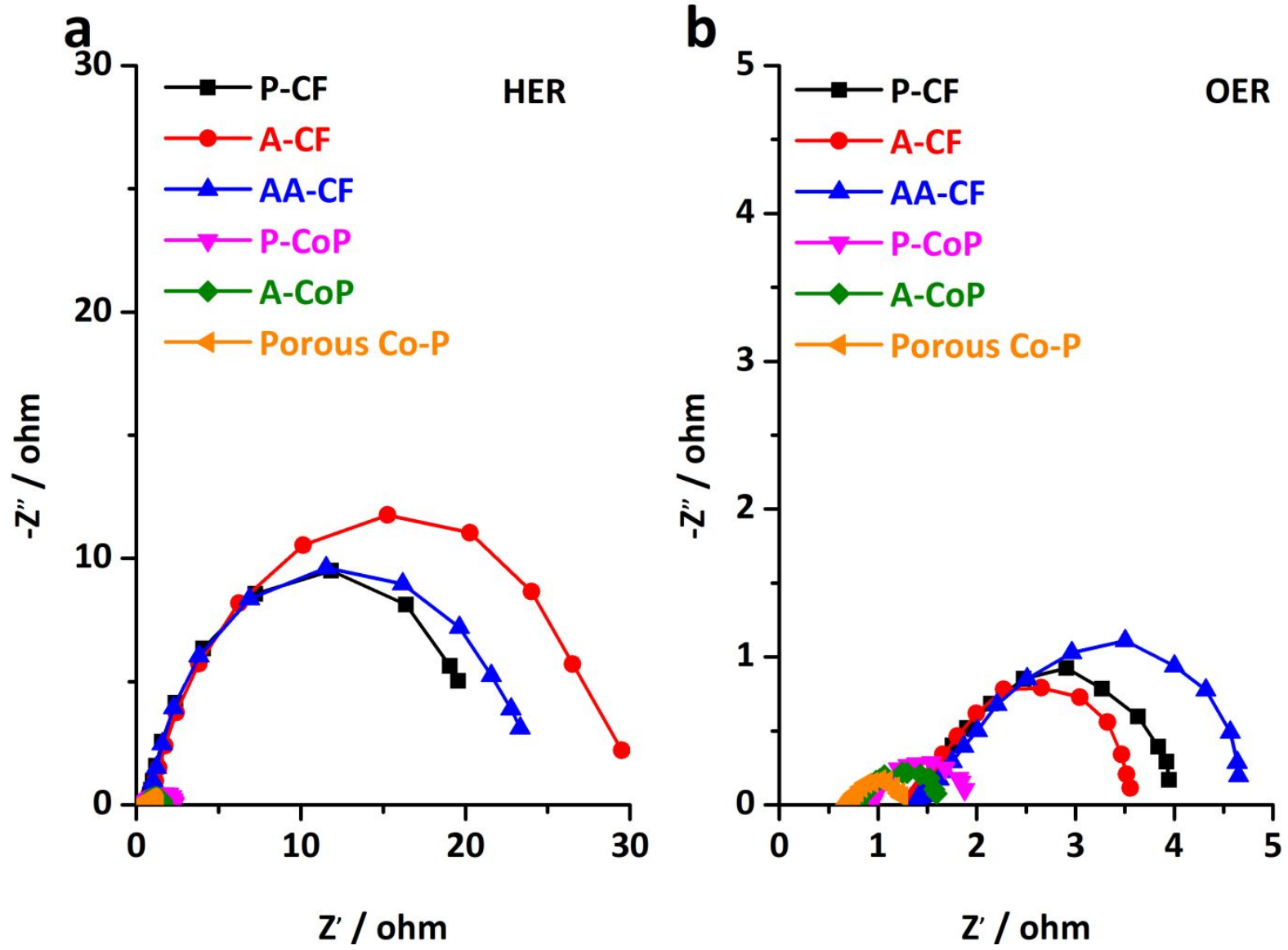

Figure S16 The Nyquist plots of porous Co-P foam and other control samples measured at (a) $\eta=200 \mathrm{mV}$ for HER and (b) $\eta=320 \mathrm{mV}$ for OER. 
a

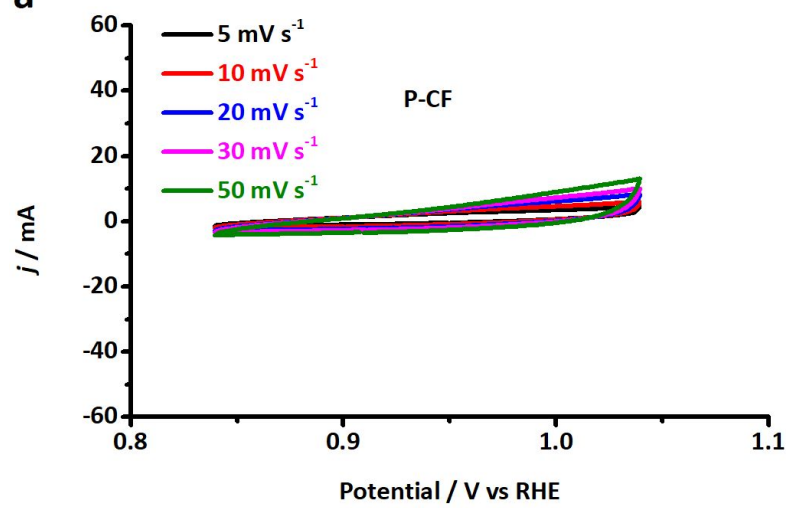

C

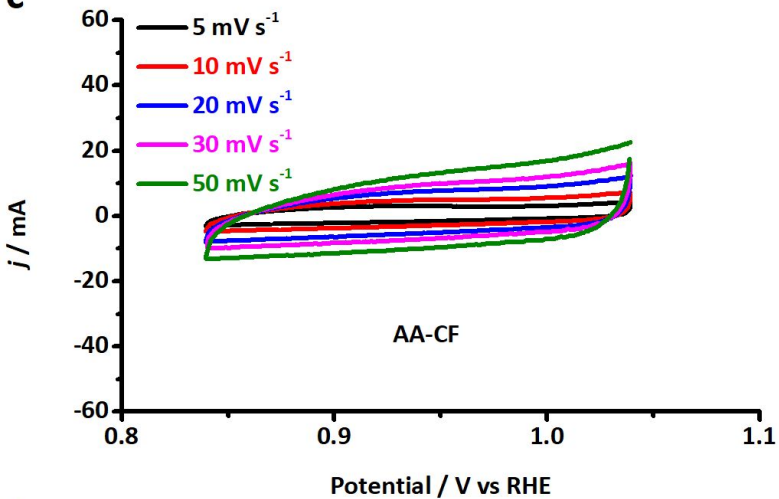

e

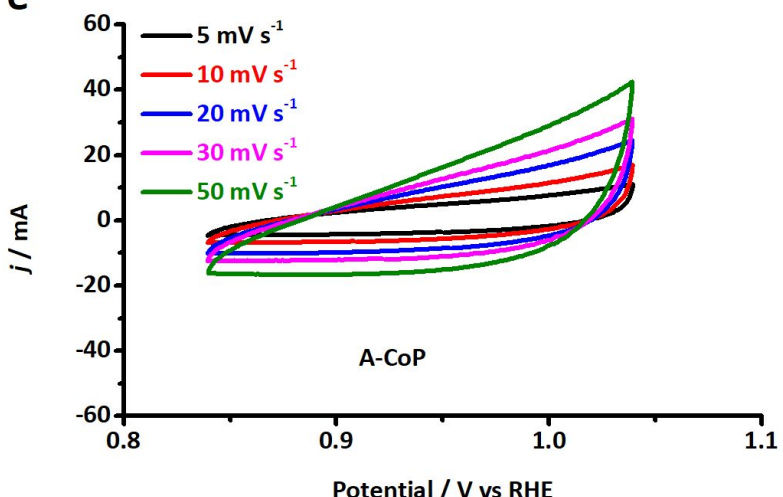

Potential / V vs RHE

$\mathrm{g}$

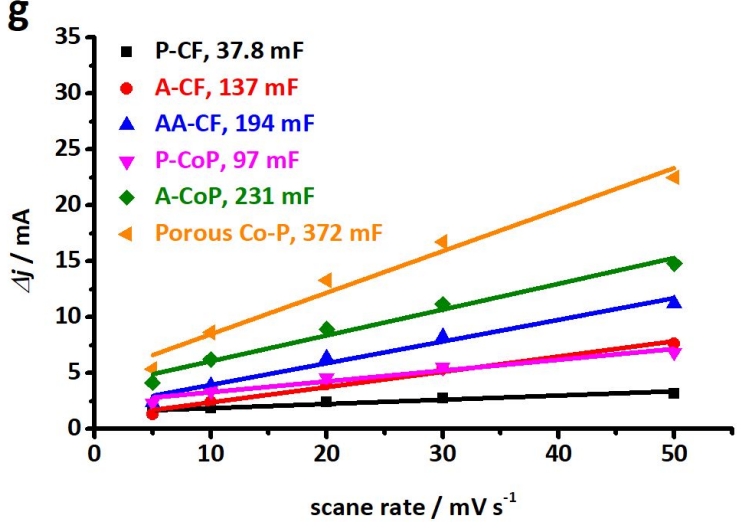

b

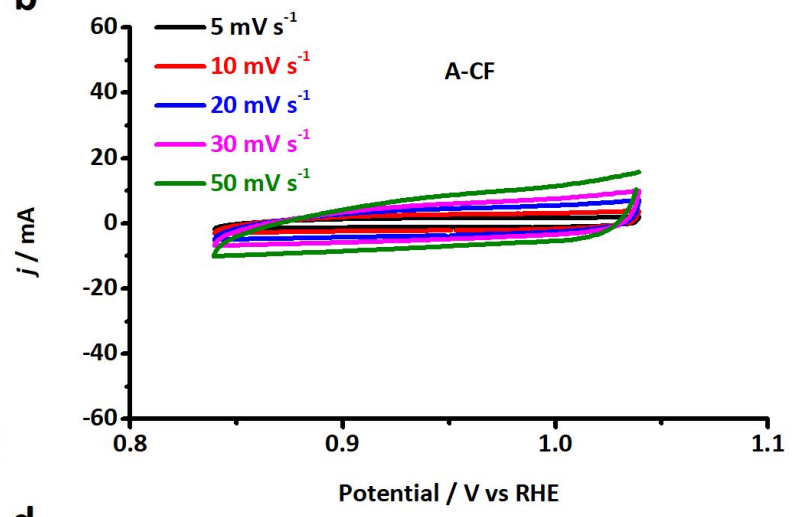

d

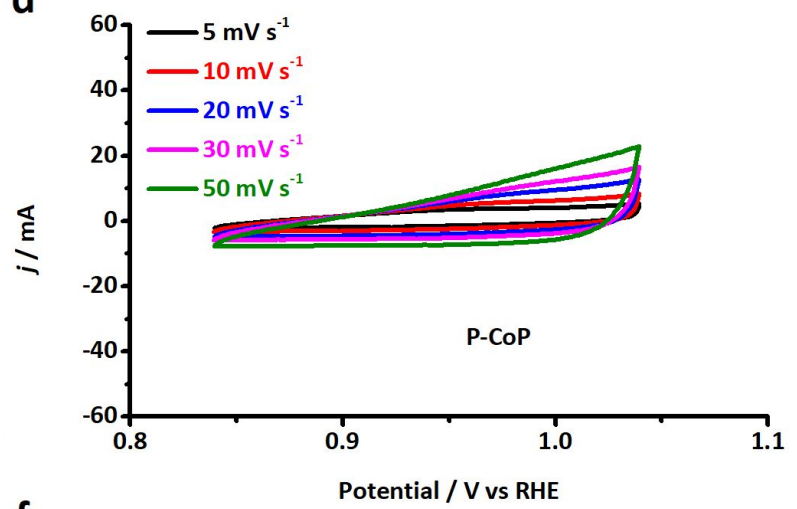

f

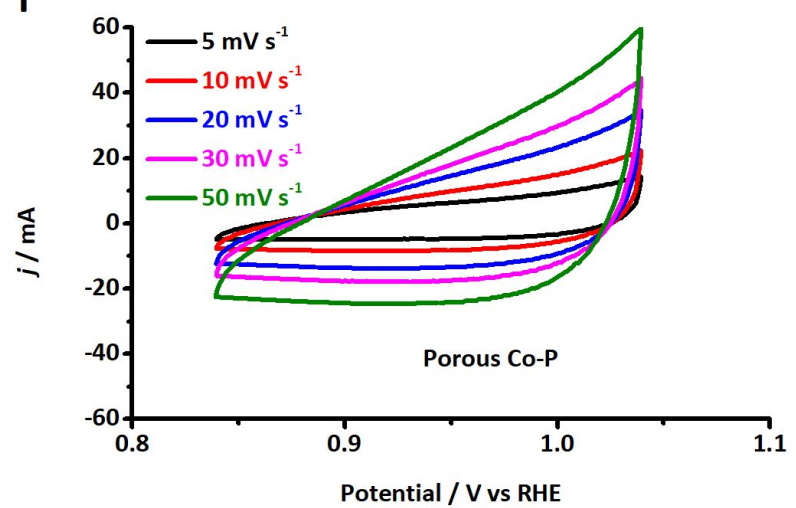

Figure S17 Electrochemical CV curves of (a) P-CF, (b) A-CF, (c) AA-CF, (d) P-CoP, (e) A$\mathrm{CoP}$ and (f) porous Co-P recorded at different scan rates of 5, 10, 20, 30 and $50 \mathrm{mV} \mathrm{s}^{-1} \cdot(\mathrm{g})$ Plots of the capacitive currents as a function of the scan rate for all the samples. 


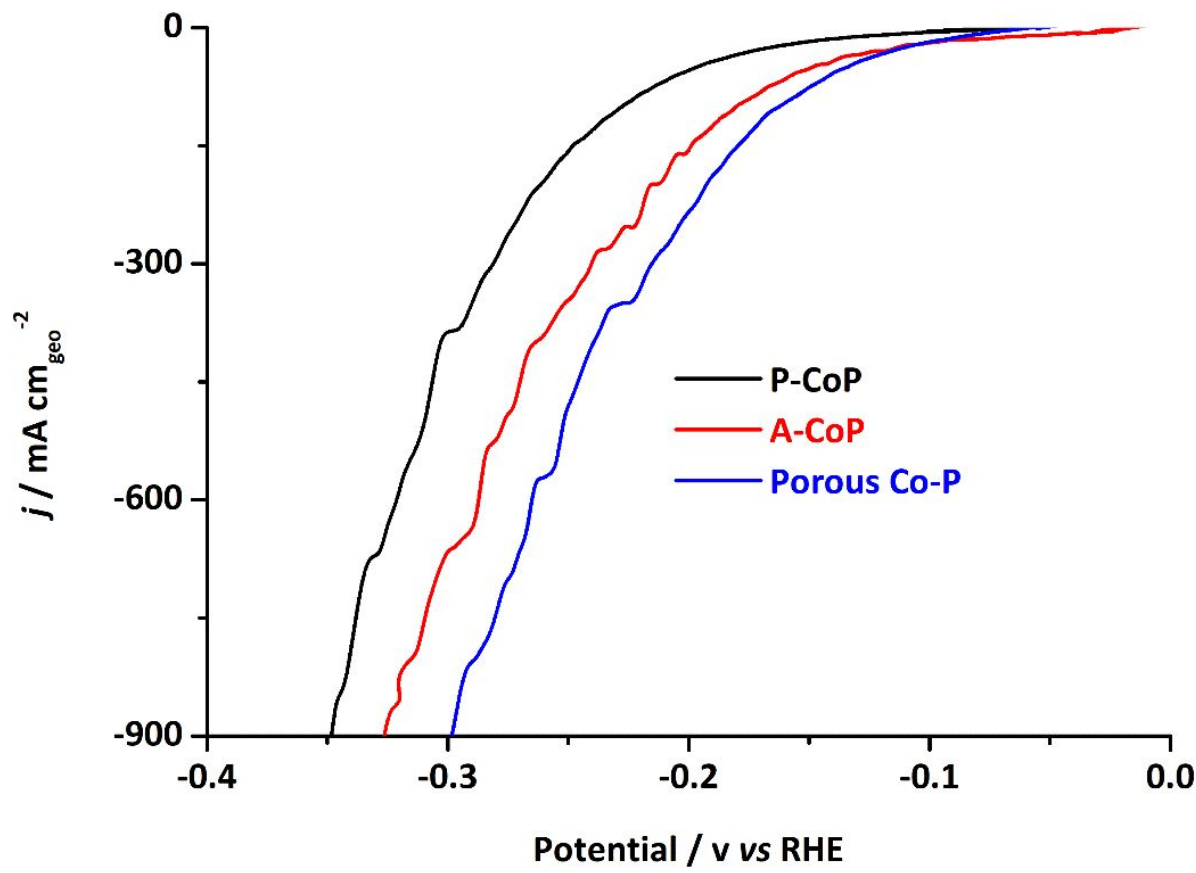

Figure S18 $i R$-corrected polarization curves of $\mathrm{P}-\mathrm{CoP}, \mathrm{A}-\mathrm{CoP}$ and porous $\mathrm{Co}-\mathrm{P}$ recorded at a scan rate of $5 \mathrm{mV} \mathrm{s}^{-1}$ for HER in $0.5 \mathrm{M} \mathrm{H}_{2} \mathrm{SO}_{4}$. 


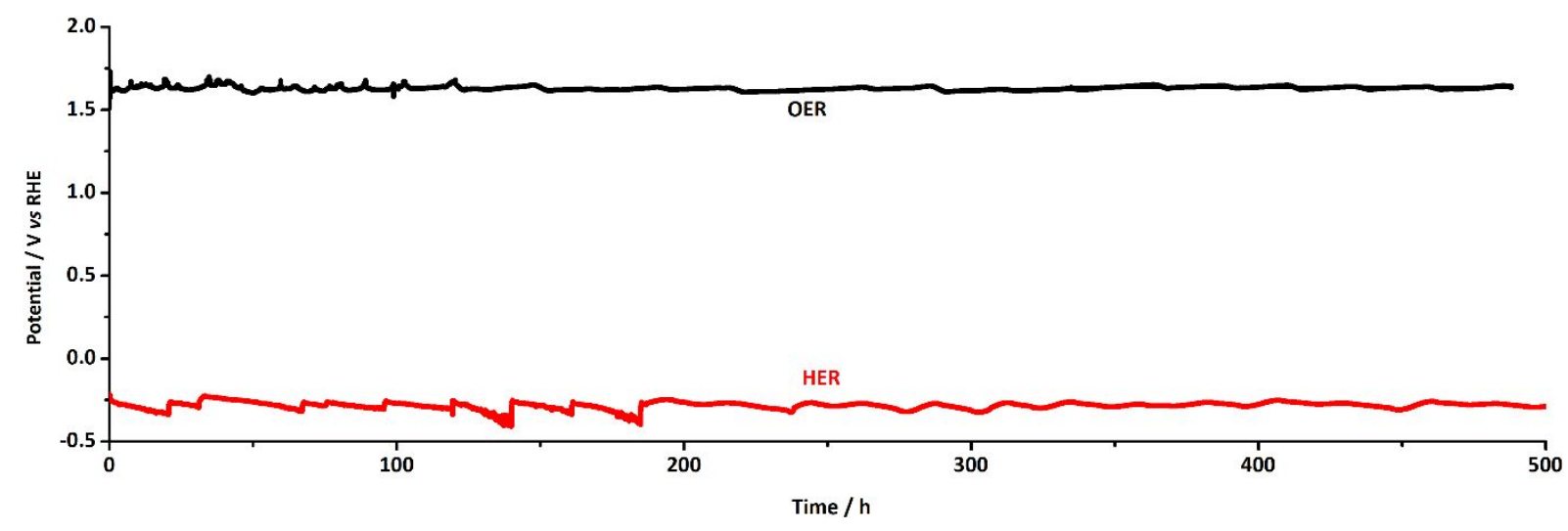

Figure S19 $i R$-corrected chronopotentiometric curves of porous Co-P recorded at a constant current density of 500 (OER) and -500 (HER) $\mathrm{mA} \mathrm{cm}^{-2}$ in $1.0 \mathrm{M} \mathrm{KOH}$. 


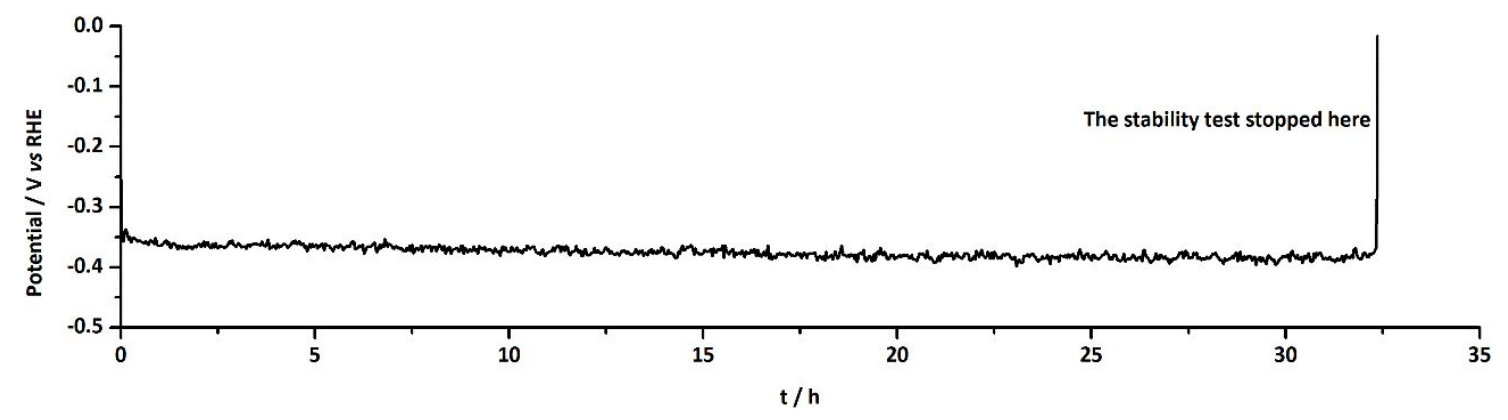

Figure S20 $i R$-corrected chronopotentiometric curves of porous Co-P recorded at a constant current density of -1000 (HER) $\mathrm{mA} \mathrm{cm}^{-2}$ in $0.5 \mathrm{M} \mathrm{H}_{2} \mathrm{SO}_{4}$. The experiments was stopped when the graphite rod counter electrode broke. 


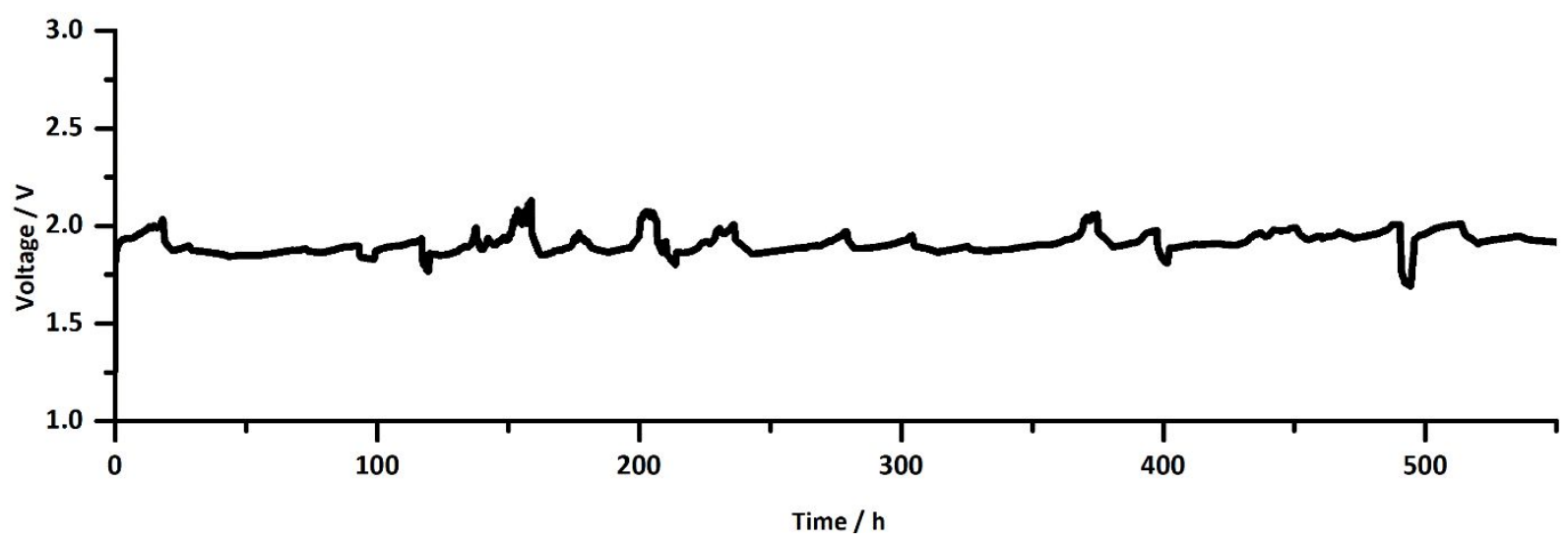

Figure S21 The stability of porous Co-P electrodes for overall water splitting recorded at a constant current density of $500 \mathrm{~mA} \mathrm{~cm}^{-2}$ with $i R$-correction. 

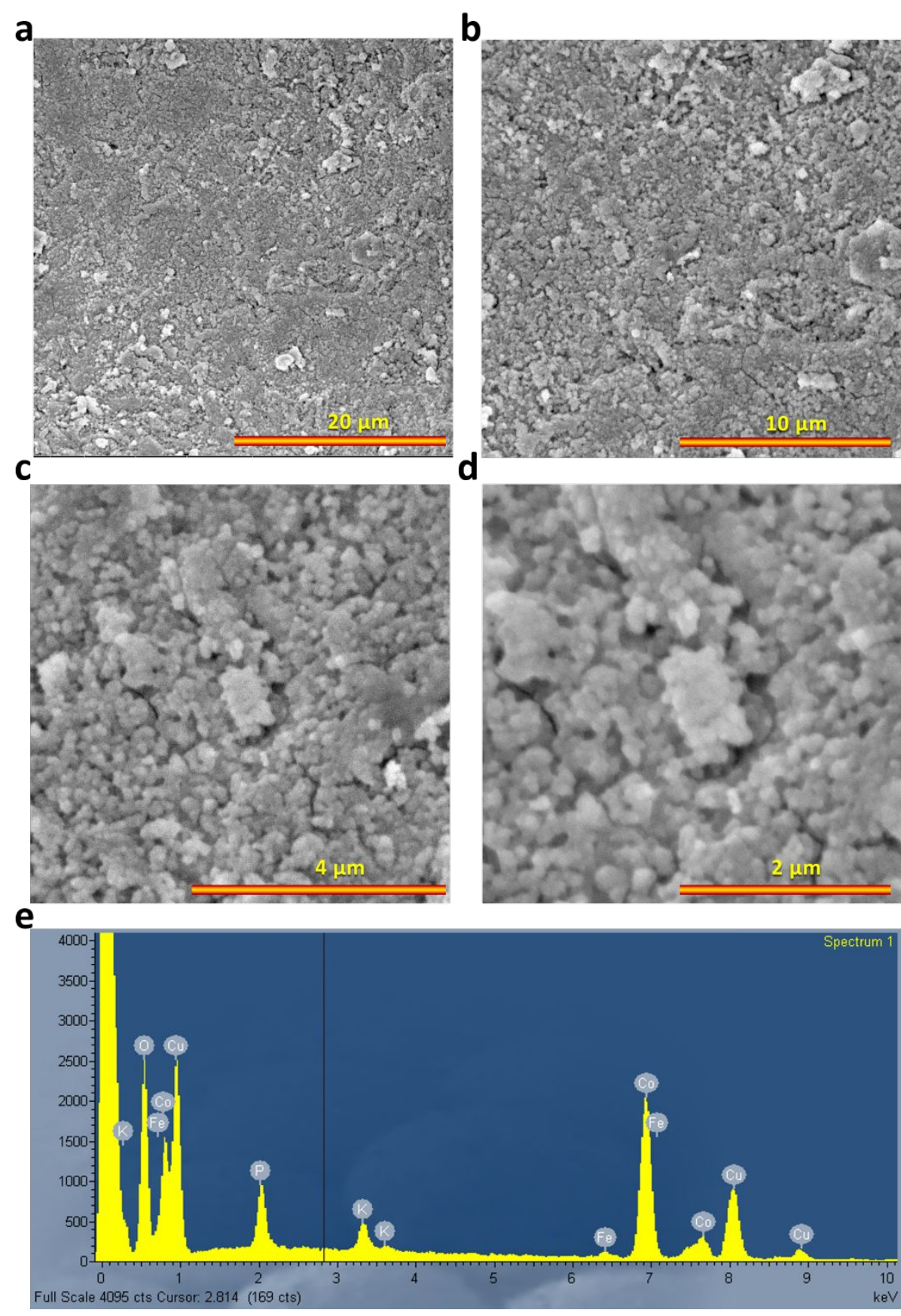

Figure S22 (a-d) SEM and (e) EDX spectrum of the porous Co-P cathode after the extended overall water electrolysis test at $1000 \mathrm{~mA} \mathrm{~cm}^{-2}$ for $4000 \mathrm{~h} . \mathrm{K}$ and $\mathrm{Fe}$ are originated from the remnant $\mathrm{KOH}$ solution, and $\mathrm{Cu}$ results from the copper tape used for SEM examination. 


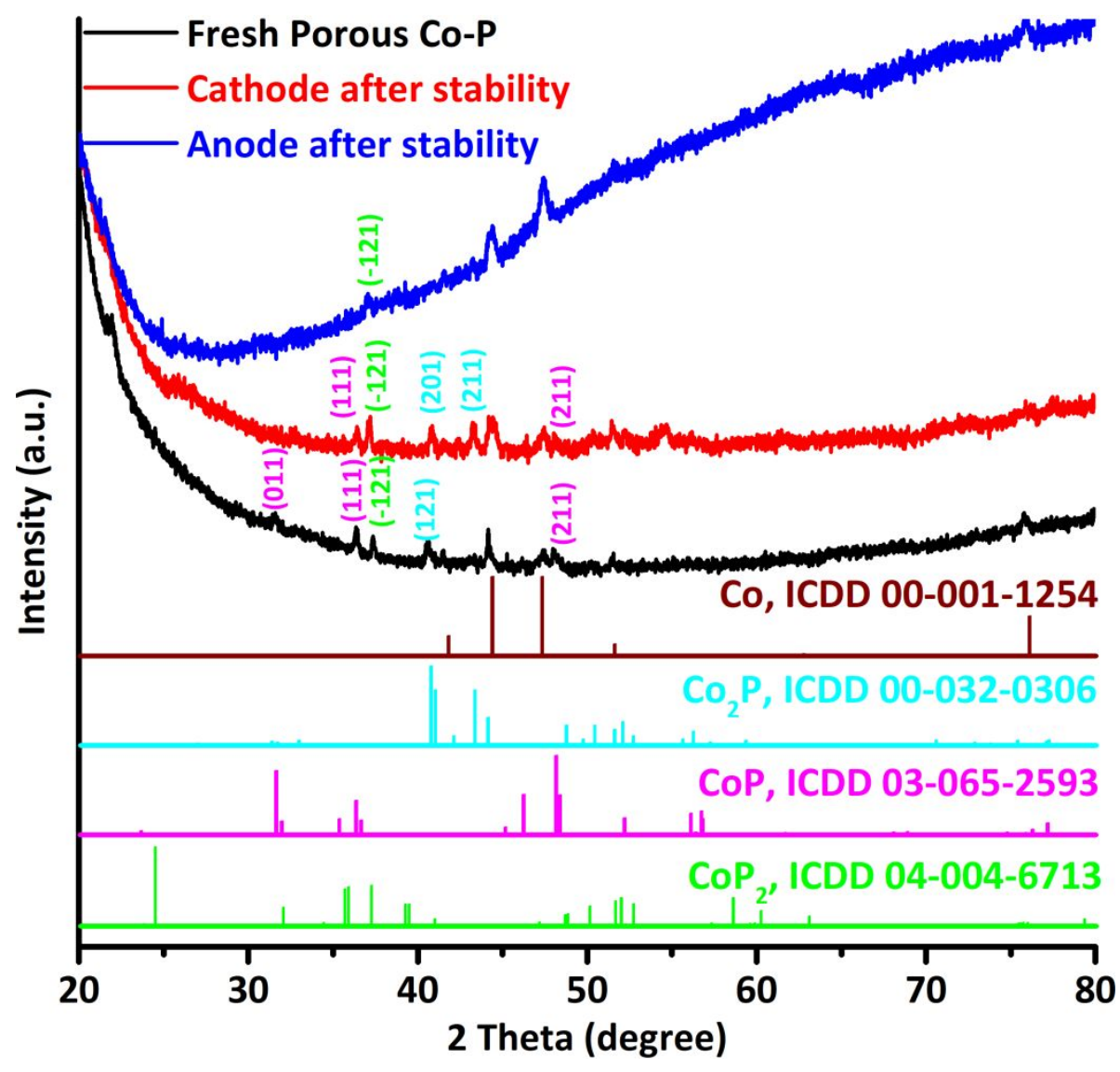

Figure S23 XRD patterns of the porous Co-P foam before and after the extended stability test in $\left.1.0 \mathrm{M} \mathrm{KOH} \mathrm{(1000} \mathrm{mA} \mathrm{cm}{ }^{-2}, 4000 \mathrm{~h}\right)$. 

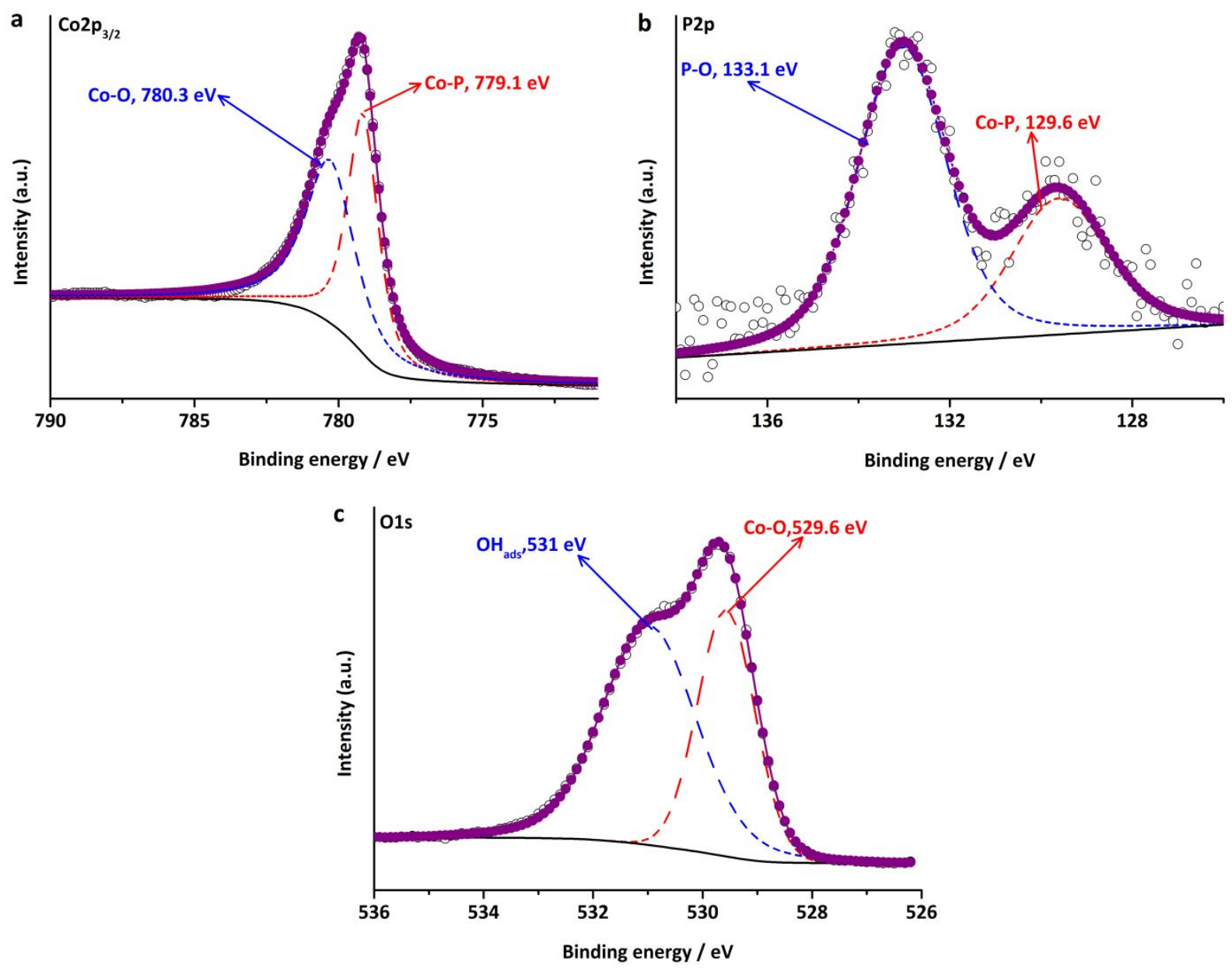

Figure S24 XPS spectra of the porous Co-P cathode after the extended overall water electrolysis test at $1000 \mathrm{~mA} \mathrm{~cm}^{-2}$ for $4000 \mathrm{~h}$ in $1.0 \mathrm{M} \mathrm{KOH}$. (a) Co2 $\mathrm{p}_{3 / 2}$ (b) P2p and (c) O1s spectra. 

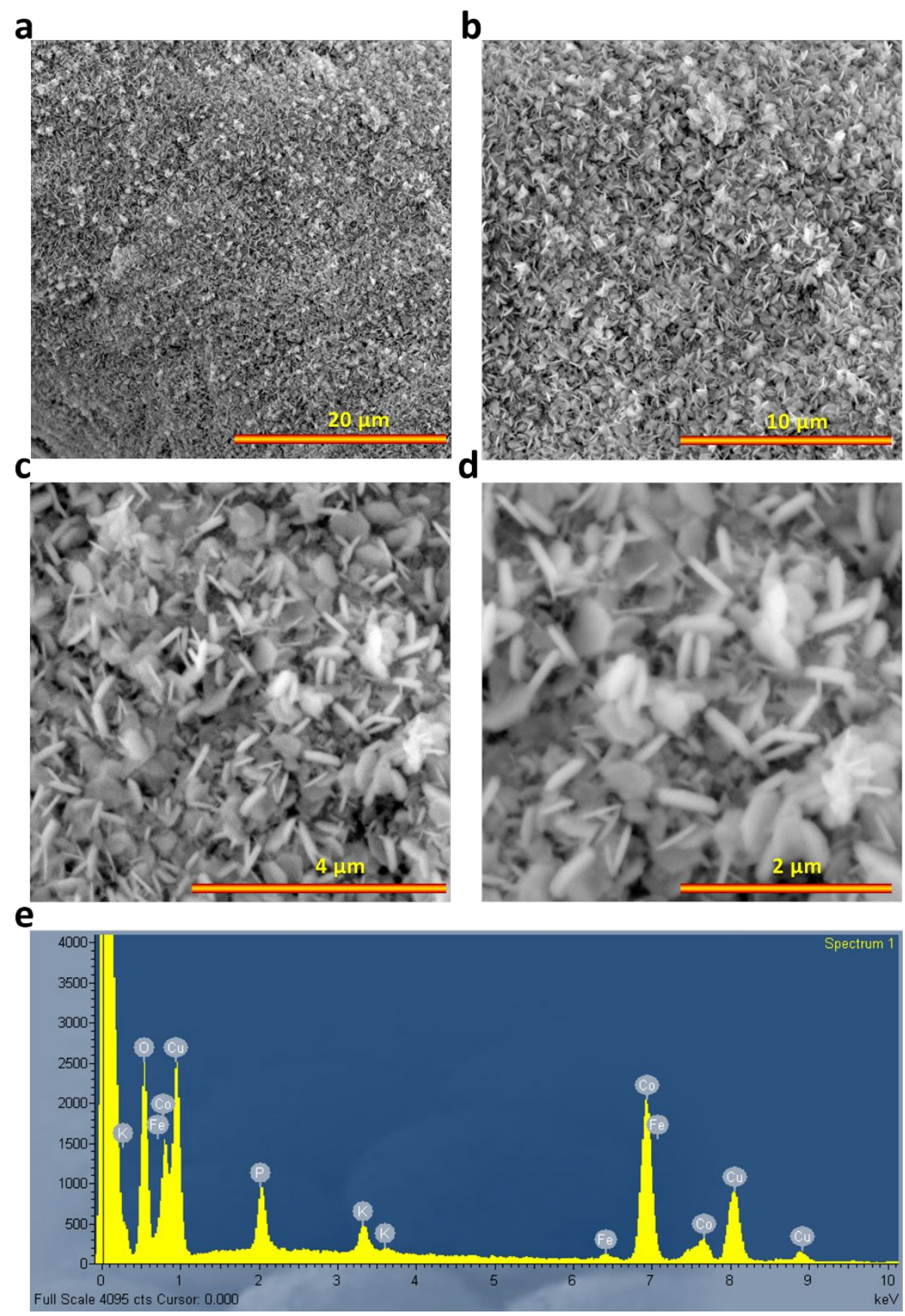

Figure S25 (a-d) SEM and (e) EDX spectrum of the porous Co-P anode after the extended overall water electrolysis test at $1000 \mathrm{~mA} \mathrm{~cm}^{-2}$ for $4000 \mathrm{~h} . \mathrm{K}$ and $\mathrm{Fe}$ are originated from the remnant $\mathrm{KOH}$ solution, and $\mathrm{Cu}$ results from the copper tape used for SEM examination. 

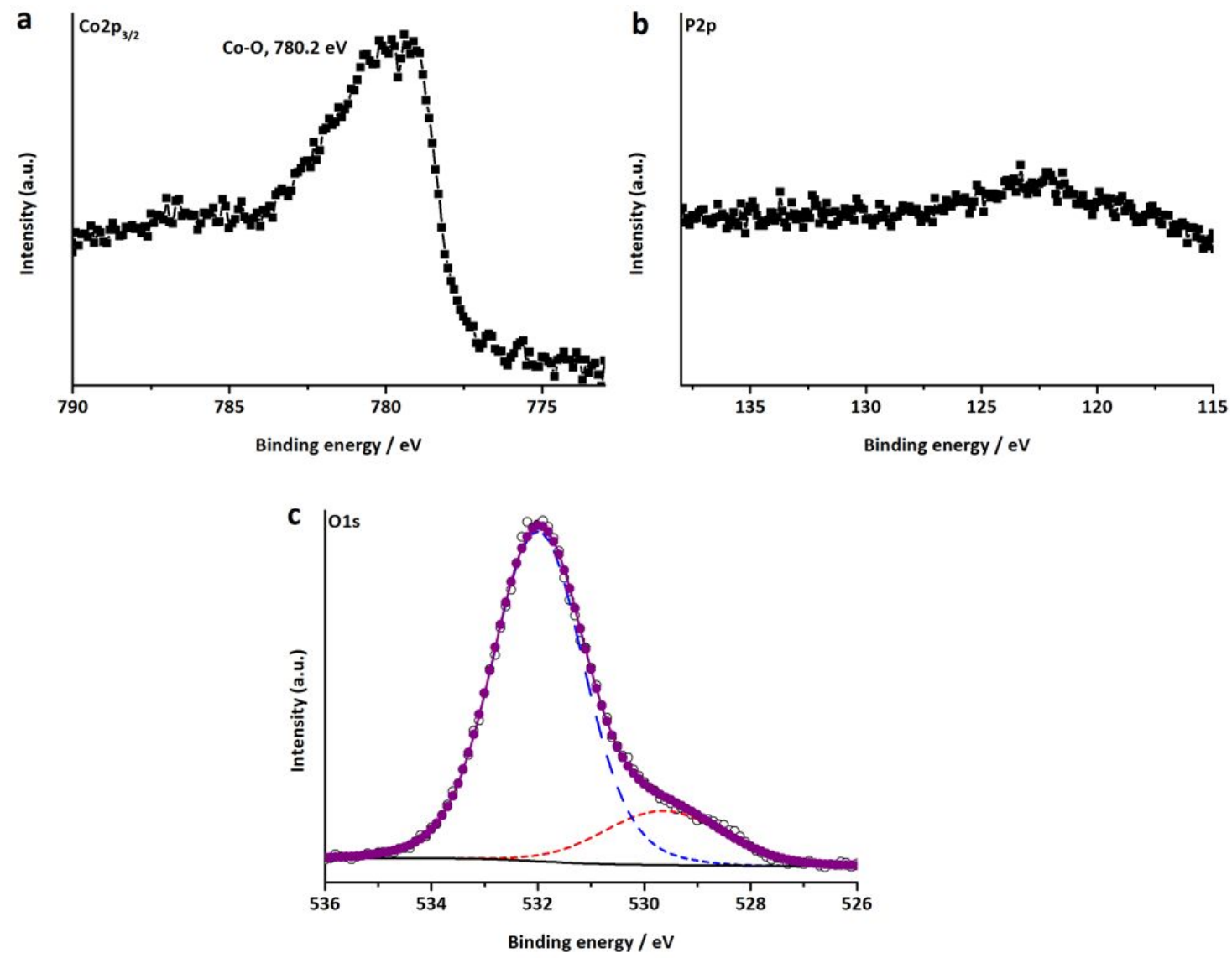

Figure S26 XPS spectra of the porous Co-P anode after the extended overall water electrolysis test at $1000 \mathrm{~mA} \mathrm{~cm}^{-2}$ for $4000 \mathrm{~h}$ in $1.0 \mathrm{M} \mathrm{KOH}$. (a) Co2p $\mathrm{p}_{3 / 2}$ (b) P2p and (c) O1s spectra. 


\section{Supporting Tables}

Table S1. Comparison of overall water splitting performance with a variety of state-of-the-art catalysts in $1.0 \mathrm{M} \mathrm{KOH}$ electrolyte.

\begin{tabular}{|c|c|c|c|c|}
\hline Catalysts & $\begin{array}{c}\mathrm{j} \\
\left(\mathrm{mA} \mathbf{c m}^{-2}\right)\end{array}$ & $\begin{array}{c}\text { Voltage }_{j} \\
\text { (V) }\end{array}$ & Stability & Reference \\
\hline porous Co-P\|porous Co-P & $\begin{array}{c}100 \\
500 \\
1000 \\
1500\end{array}$ & $\begin{array}{l}1.65 \\
1.85 \\
1.98 \\
2.07\end{array}$ & $4000 \mathrm{~h} @ 1000 \mathrm{~mA} \mathrm{~cm}{ }^{-2}$ & This work \\
\hline $\mathrm{FeNi}(\mathrm{BDC})(\mathrm{DMF}, \mathrm{F}) / \mathrm{NF} \| \mathrm{FeNi}(\mathrm{BDC})(\mathrm{DMF}, \mathrm{F}) / \mathrm{NF}$ & 400 & 1.90 & $30 \mathrm{~h} @ 400 \mathrm{~mA} \mathrm{~cm}{ }^{-2}$ & $\begin{array}{c}\text { Appl. Catal. B-Environ., 2019, 258, } \\
118023\end{array}$ \\
\hline MFN-MOFs/NF\|MFN-MOFs/NF & 500 & 1.8 & $100 \mathrm{~h} @ 500 \mathrm{~mA} \mathrm{~cm}{ }^{-2}$ & Nano Energy, 2019, 57, 1-13 \\
\hline NiFe-LDH/MXene/NF\|NiFe-LDH/MXene/NF & 500 & 1.75 & $200 \mathrm{~h} @ 100 \mathrm{~mA} \mathrm{~cm}{ }^{-2}$ & Nano Energy, 2019, 63, 103880 \\
\hline $\begin{array}{c}\mathrm{Fe}_{2} \mathrm{O}_{3} @ \mathrm{Ni}_{2} \mathrm{P} / \mathrm{Ni}\left(\mathrm{PO}_{3}\right)_{2} / \mathrm{NF} \| \mathrm{Fe}_{2} \mathrm{O}_{3} @ \mathrm{Ni}_{2} \mathrm{P} / \mathrm{Ni}\left(\mathrm{PO}_{3}\right)_{2} / \\
\mathrm{NF}\end{array}$ & 1000 & 3.02 & $10 \mathrm{~h} @ 3.0 \mathrm{~V}$ & J. Mater. Chem. A, 2019, 7, 965-971 \\
\hline $\mathrm{Ni}-\mathrm{Fe}) \mathrm{S}_{\mathrm{x}} / \mathrm{NiFe}(\mathrm{OH})_{\mathrm{y}} / \mathrm{NF} \|(\mathrm{Ni}-\mathrm{Fe}) \mathrm{S}_{\mathrm{x}} / \mathrm{NiFe}(\mathrm{OH})_{\mathrm{y}} / \mathrm{NF}$ & 1200 & 2.2 & $50 \mathrm{~h} @ 1000 \mathrm{~mA} \mathrm{~cm}{ }^{-2}$ & $\begin{array}{l}\text { Appl. Catal. B-Environ., 2019, 46, } \\
\text { 337-348 }\end{array}$ \\
\hline Co-S-50/NF\|Co-S-50/NF & 500 & 2.08 & $110 \mathrm{~h} @ 500 \mathrm{~mA} \mathrm{~cm}{ }^{-2}$ & J. Power Sources, 2019, 436, 226887 \\
\hline $\mathrm{NiFe} / \mathrm{NiFe}$ & 400 & 2.16 & $24 \mathrm{~h} @ 400 \mathrm{~mA} \mathrm{~cm}{ }^{-2}$ & $\begin{array}{l}\text { ACS Appl. Mater. Interfaces, } 2019, \\
\quad \mathbf{1 1}, 24096-24106\end{array}$ \\
\hline $\mathrm{NiFe} /(\mathrm{Ni}, \mathrm{Fe})_{3} \mathrm{~S}_{2} \| \mathrm{NiFe} /(\mathrm{Ni}, \mathrm{Fe})_{3} \mathrm{~S}_{2}$ & 400 & 1.9 & $24 \mathrm{~h} @ 400 \mathrm{~mA} \mathrm{~cm}{ }^{-2}$ & Small Methods, 2019, 3, 1900234 \\
\hline $\mathrm{Fe}-\mathrm{Ni}_{3} \mathrm{~S}_{2} / \mathrm{NF} \| \mathrm{Fe}-\mathrm{Ni}_{3} \mathrm{~S}_{2}$ & 500 & 1.95 & $14 \mathrm{~h} @ 500 \mathrm{~mA} \mathrm{~cm}{ }^{-2}$ & $\begin{array}{l}\text { ChemElectroChem, 2019, 6, 4550- } \\
4559\end{array}$ \\
\hline CoNiMo-O $\| \mathrm{CoNiMo-O}$ & 1000 & 2.03 & $20 \mathrm{~h} @ 1000 \mathrm{~mA} \mathrm{~cm}{ }^{-2}$ & ChemElectroChem, 2019, 6, 413-420 \\
\hline $\mathrm{Co}_{2} \mathrm{P}-\mathrm{Co}_{3} \mathrm{O}_{4} / \mathrm{Till}_{2} \mathrm{Co} / \mathrm{Ti}$ & 500 & 3.36 & $\begin{array}{l}24 \mathrm{~h} @ \text { current step from } \\
10 \text { to } 500 \mathrm{~mA} \mathrm{~cm}^{-2}\end{array}$ & $\begin{array}{l}\text { Adv. Energy Mater., } 2018, \mathbf{8} \\
1802445\end{array}$ \\
\hline B-NFN-MOF/NF\|B-NFN-MOF/NF & 500 & 1.96 & $30 \mathrm{~h} @ 500 \mathrm{~mA} \mathrm{~cm}{ }^{-2}$ & $\begin{array}{l}\text { Adv. Energy Mater., } 2018, \mathbf{8} \\
1801065\end{array}$ \\
\hline $\mathrm{Ni}_{2(1-\mathrm{x})} \mathrm{Mo}_{2 \mathrm{x}} \mathrm{P} / \mathrm{NF} \| \mathrm{Ni}_{2(1-\mathrm{x})} \mathrm{Mo}_{2 \mathrm{x}} \mathrm{P} / \mathrm{NF}$ & 500 & 1.82 & ca. $25 \mathrm{~h} @ 500 \mathrm{~mA} \mathrm{~cm}{ }^{-2}$ & Nano Energy, 2018, 53, 492-500 \\
\hline $\mathrm{CoNi} / \mathrm{CoFe}_{2} \mathrm{O}_{4} / \mathrm{NF} \| \mathrm{CoNi} / \mathrm{CoFe}_{2} \mathrm{O}_{4} / \mathrm{NF}$ & 100 & 1.75 & $48 \mathrm{~h} @ 100 \mathrm{~mA} \mathrm{~cm}{ }^{-2}$ & $\begin{array}{l}\text { J. Mater. Chem. A, 2018, 6, 19221- } \\
19230\end{array}$ \\
\hline $\mathrm{NiFe}_{2} \mathrm{O}_{4} / \mathrm{NiFe} \mathrm{LDH} / \mathrm{NF} \| \mathrm{NiFe}_{2} \mathrm{O}_{4} / \mathrm{NiFe} \mathrm{LDH} / \mathrm{NF}$ & 500 & 1.932 & $20 \mathrm{~h} @ 1.94 \mathrm{~V}$ & $\begin{array}{c}\text { ACS Appl. Mater. Interfaces, 2018, } \\
\mathbf{1 0}, 26283-26292\end{array}$ \\
\hline $\mathrm{Fe}^{0}-\mathrm{NixSy} / \mathrm{NF} \| \mathrm{Fe}^{0}-\mathrm{NixSy} / \mathrm{NF}$ & 1000 & 3.0 & $10 \mathrm{~h} @ 500 \mathrm{~mA} \mathrm{~cm}{ }^{-2}$ & $\begin{array}{l}\text { ChemElectroChem, 2018, 5, 3866- } \\
\qquad 3872\end{array}$ \\
\hline $\mathrm{CoP} / \mathrm{CF} \| \mathrm{CoP} / \mathrm{CF}$ & 100 & 1.78 & $1000 \mathrm{~h} @ 100 \mathrm{~mA} \mathrm{~cm}{ }^{-2}$ & Chem. Sci., 2017, 8, 2952-2958 \\
\hline
\end{tabular}

